\title{
Directors' and officers' liability insurance and acquisition outcomes ${ }^{*}$
}

\author{
Chen Lin \\ Chinese University of Hong Kong \\ Email: chenlin@baf.msmail.cuhk.edu.hk \\ Telephone: +852 26098566 \\ Micah Officer \\ Loyola Marymount University \\ Email: micah.officer@lmu.edu \\ Telephone: (310) 338-7658 \\ Hong Zou \\ City University of Hong Kong \\ Email: hongzou@cityu.edu.hk \\ Telephone: +85234427880
}

\begin{abstract}
We examine the effect of directors' and officers' liability insurance (D\&O insurance) on the outcomes of merger and acquisition (M\&A) decisions. We find that acquirers whose executives have a higher level of D\&O insurance coverage experience significantly lower announcementperiod abnormal stock returns. Further analyses suggest that acquirers with a higher level of $\mathrm{D} \& \mathrm{O}$ insurance protection tend to pay higher acquisition premiums and their acquisitions appear to exhibit lower synergies. The evidence provides support for the notion that the provision of $\mathrm{D} \& \mathrm{O}$ insurance can induce unintended moral hazard by shielding directors and officers from the discipline of shareholder litigation.
\end{abstract}

\footnotetext{
* We thank Tom Bates, David Becher, Xuanjuan Chen, Brad Cornell, Eli Fich, Stu Gillan, Jarrad Harford, Cong Wang, Tong $\mathrm{Yu}$, an anonymous referee, and seminar participants at Charles River Associates and Drexel University for very helpful comments. We appreciate the research assistance of Joyce Li, Li Li, Hoi Lo, Chunning Ma, and Erik Wang. We acknowledge the financial support from City University of Hong Kong and Loyola Marymount University.
} 


\section{Introduction}

Using a unique data set of directors' and officers' liability insurance (hereafter referred to as "D\&O insurance") manually collected for Canadian firms, in this paper we examine the impact of $\mathrm{D} \& \mathrm{O}$ insurance on the outcome of corporate acquisition decisions. Both $\mathrm{D} \& \mathrm{O}$ insurance and corporate indemnification provide important layers of protection to a company's directors and officers for legal liability arising from their professional activities on behalf of the company. Indemnification refers to the process by which companies agree to compensate executives for the costs of defense and/or settling lawsuits brought against them personally as a result of their service for the firm. Companies purchase D\&O insurance to recoup these indemnification costs, or to provide protection when indemnification does not apply (Core, 1997, Chung and Wynn, 2008). ${ }^{1}$ In fact, most securities class action lawsuits in the US brought by shareholders are settled out of court within the $\mathrm{D} \& \mathrm{O}$ insurance coverage limit. D\&O insurance thus serves as an important source of funds to companies for the defense and settlement of lawsuits.

For directors and officers, D\&O insurance can provide an additional layer of protection in two scenarios. First, indemnification is only effective if the corporation is sufficiently solvent to cover the executives' costs. If the company is insolvent, $\mathrm{D} \& \mathrm{O}$ insurance is the only available source of protection for directors and officers (Core, 1997; Boyer, 2005). Second, subject to corporate bylaws, a corporation can indemnify directors and officers for damages, settlement amounts, and legal expenses only if the directors and officers have acted in good faith and in the best interests of the corporation. In contrast, the most typical exclusions from D\&O insurance coverage are suits based on deliberate fraud and illegal profit. ${ }^{2}$ As Black, Cheffins, and Klausner

\footnotetext{
${ }^{1}$ A D\&O policy may include the following protections: a) coverage to protect individual directors and officers from liability in litigation when the company is not able to indemnify them for legal reasons, due to financial distress, or when a firm is permitted to do so (by law and the company's bylaws) but chooses not to (i.e., the socalled "Side A" coverage); b) coverage to reimburse the company for indemnity payments made to directors and officers when it indemnifies directors and officers for legal costs or penalties awarded against them (i.e., the "Side B" coverage; this coverage does not typically cover any liability the company itself may have to the plaintiff); c) coverage to protect the firm from the risk of litigation when the company is directly sued as a defendant (i.e., the "Side C" coverage). Side A coverage typically includes no deductible (loss sharing by the insured) but Side B and Side C often do; Side A coverage can be purchased separately (Baker and Griffith, 2007).

${ }^{2}$ In practice, there is little evidence of insurers contesting D\&O insurance coverage offered in Canada as long as directors and officers do not admit to dishonesty (Cheffins and Black, 2006, p.1448).
} 
(2006, p.1086) point out, “... the deliberate fraud and personal profit exclusions are considerably narrower than the good faith limitation on indemnification since the exclusions contemplate some form of actual dishonesty, whereas the good faith standard will be breached if there has been a 'conscious disregard for one's responsibilities.",3 Therefore, D\&O insurance typically provides less restrictive protections for directors and officers than corporate indemnification does. Despite these subtle differences, in practice the business judgment rule sets a relatively high hurdle for proving breach of fiduciary duty and the risk of insolvency for many listed firms is not high. Therefore, whether D\&O insurance exerts an impact on corporate decisions remains an empirical question that we explore in this study.

We find that acquirers whose managers are protected by D\&O insurance, or carry higher policy limits, experience significantly lower announcement-period abnormal stock returns around merger and acquisition (M\&A) announcements than do acquirers whose managers are not protected by D\&O insurance (or carry lower policy limits). We then seek to understand why acquirers with D\&O insurance experience lower stock returns around acquisition announcements by exploring two channels. First, when we examine the effect of D\&O insurance on acquisition premiums paid by acquirers, we find that acquirers with more D\&O insurance tend to pay higher premiums. We also examine the synergies in the M\&A deals for firms with high or low D\&O insurance coverage. Combined (acquirer plus target) cumulative abnormal announcement returns are lower in deals where the acquirer carries high (above sample median) insurance coverage. Subsequent operating performance of the merged firm also appears to be negatively related to the D\&O insurance coverage carried by the acquirer. Together, our findings provide evidence that managers of firms carrying high levels of $\mathrm{D} \& \mathrm{O}$ insurance make poor M\&A decisions (high premiums paid and low synergies received) that result in lower returns for their stockholders. However, while our study identifies one potential cost of D\&O insurance in the M\&A setting, it

\footnotetext{
${ }^{3}$ In Canada, the Canada Business Corporations Acts (CBCA) amendments made in 2001 eliminated the "breach of fiduciary duty" restriction for D\&O insurance coverage, which further increases the importance of D\&O insurance to directors and officers.
} 
cannot address whether D\&O insurance unambiguously increases or decreases firm value.

The purchase of D\&O insurance is very common for listed companies in many common-law jurisdictions (e.g., the US and Canada). For example, in our sample we find that over $70 \%$ of acquirers carry D\&O insurance coverage, and in other samples the proportion of firms covered by D\&O insurance is even higher (see Tillinghast-Towers Perrin, 2002). Nevertheless, there is an ongoing debate about the merits and costs of $\mathrm{D} \& \mathrm{O}$ insurance. One view is that because $\mathrm{D} \& \mathrm{O}$ insurance insulates directors and officers from the threat of litigation and personal financial liability resulting from their decisions on behalf of the corporation, it reduces managerial incentives to act in the best interest of shareholders. The other view is that D\&O insurance can be beneficial to shareholders because the scrutiny of a firm's corporate governance by the D\&O insurer in underwriting provides monitoring (Holderness, 1990; Core, 2000), D\&O insurers have comparative advantages in providing claims adjudication/settlement services (Mayers and Smith, 1982), D\&O insurers act as deep-pocket, last-chance payers for shareholders who suffer losses because of managerial mistakes (Boyer, 2005), and D\&O insurance can help a firm attract highcaliber candidates as directors and officers and may reduce the compensating differential in executive pay (Mayers and Smith, 1982), or help lower a firm's incidence of bankruptcy (Core, 1997; Zou and Adams, 2008). The problems/merits of D\&O insurance have received heightened attention in recent years amid debate about whether securities class action lawsuits should be the primary means of providing remedies to injured investors and reform of the class action system in the US (Seligman, 2004). ${ }^{4}$

Despite the prevalence of D\&O insurance and the debate about its merits, empirical evidence is relatively sparse due largely to the difficulty in obtaining D\&O insurance data at the firm level. Using a proprietary sample of 72 initial public offerings (IPOs) in the US, Chalmers, Dann, and Harford (2002) find a negative relation between the amount of D\&O insurance purchased at the

\footnotetext{
${ }^{4}$ These alleged problems with D\&O insurance include: the existence of D\&O insurance could cause moral hazard among directors and officers, attract frivolous shareholder suits, and induce parties in a suit to settle out-ofcourt (before proceeding to the trial) because once the defendant loses a suit, D\&O insurance cannot be used to pay damages.
} 
time of the IPO and three-year post-IPO stock returns, suggesting that managerial opportunism affects D\&O insurance decisions. Core (1997) and Gillan and Panasian (2010a) find that corporate governance and managerial entrenchment are associated with D\&O insurance decisions. Core (2000), Gillan and Panasian (2010a, 2010b), and Stern and Boyer (2010) further note that D\&O insurance premiums vary predictably with firm-specific factors (e.g., governance and disclosure) affecting litigation risk. Zou, Wong, Shum, Xiong, and Yan (2008) find that purchases of D\&O insurance in China are related to governance issues generated by controllingminority shareholder incentive conflicts.

In addition to the sparse attention $\mathrm{D} \& \mathrm{O}$ insurance has received in the literature, these existing studies invariably focus on understanding the key determinants of D\&O insurance purchases and premiums; as a result, we still know little about the effects of D\&O insurance on important corporate decisions. ${ }^{5}$ Chalmers et al. $(2002$, p.633) note that further research in understanding the implications of a firm's choice of D\&O insurance coverage is warranted. While the nominal policy amounts in D\&O insurance are relatively small compared to the size of the firms carrying the coverage (in our sample, for example, the average nominal policy limit is C $\$ 46.5$ million), the incentive effects of D\&O insurance could be substantial because the policy limits are large relative to the net worth of the executives that make the decisions that could result in litigation (and substantial expense to those executives).

In this paper, we take advantage of the mandatory disclosure requirement of D\&O insurance policies by listed firms in Canada and examine the effects of D\&O insurance on the outcomes for acquirers in mergers and acquisitions (M\&As). ${ }^{6}$ M\&As are an interesting area in which to

\footnotetext{
${ }^{5}$ Bhagat, Brickley, and Coles (1987) use a sample of 11 announcements and find a positive and marginally significant market reaction to D\&O insurance purchases for New York-based firms. We attempt to pinpoint an exact channel by which D\&O insurance affects directors' and officers' incentives and corporate decisions. Chung and Wynn (2008) find that higher legal liability coverage lowers the firm's earning conservatism in financial reporting. Wynn (2008) reports that the liability coverage proxied by a firm's excess cash holding appears to affect a firm's disclosure of bad news in US listed Canadian companies.

${ }^{6}$ In contrast, US firms (except those that are based in New York) are not required to disclose D\&O insurance information (Chalmers et al., 2002), and a search of the 10-K filings of a random sample of US firms found no voluntary disclosure of such information. This is not surprising given the importance of D\&O insurance in minimizing managerial liability and that such information is often deemed to be sensitive and confidential by companies.
} 
examine the effects of D\&O insurance on corporate decision-making because M\&A investment are often lumpy and significant for many firms. D\&O insurance and M\&As are also closely related because M\&A-related lawsuits are the principal litigation risk faced by directors and officers in fiduciary duty suits (Core, 1997, 2000; Thompson and Thomas, 2004; Weiss and White, 2004). Specifically, Thompson and Thomas (2004) report that more than $80 \%$ of the fiduciary duty suits filed in Delaware between 1999 and 2000 are class actions against listed companies challenging director misconduct in M\&A decisions and that acquisition-oriented suits are now the dominant form of corporate litigation. Furthermore, Gong, Louis, and Sun (2008) find that about $21 \%$ of stock-swap mergers in the US between 1996 and 2002 result in litigation and that pre-merger abnormal accruals can predict the incidence of post-merger lawsuits, suggesting that irregularities in financial reporting and misconduct in M\&As are often entangled and frequently lead to shareholder litigations. Indeed, shareholder lawsuits in our sample often challenge whether directors and officers conduct M\&As with appropriate due diligence, the fairness of payment terms, and/or irregularities in disclosure regarding the deal (e.g., being overly optimistic or withholding important negative information). Nortel, one of our sample firms, was targeted by shareholders for misconduct in a series of acquisitions and financial misreporting. To our knowledge, however, no prior studies have examined the effect of D\&O insurance coverage on M\&A outcomes.

If the protection of D\&O insurance induces moral hazard amongst well-protected directors and officers, we predict that firms with substantial D\&O insurance coverage are more likely to make poor M\&A decisions. If directors and officers knowingly (e.g., for self interest), recklessly, or negligently make poor M\&A decisions, (operational and financial) problems will likely surface after the merger is completed and securities class actions are often triggered by a sharp decline in the company's stock price. ${ }^{7}$ This exposes directors and officers to the prospect of

\footnotetext{
7 Attorneys' fees, often recoverable from a settlement, provide strong financial incentives to some entrepreneurial lawyers to actively commence class action lawsuits on behalf of clients (Cox, 1997). The stock price fall that often accompanies M\&A transactions could be one of the factors that attracts such actions.
} 
shareholder litigation and potential personal liability, and the existence of D\&O insurance coverage can effectively eliminate or mitigate directors' and officers' personal liability for monetary damages to shareholders. As a result, the disciplinary effect of (potential) shareholder litigation is muted by $\mathrm{D} \& \mathrm{O}$ insurance.

It is also important to point out that shareholder class action lawsuits do not have to be successful, ex post, in order to impose potential litigation risk, and exert a disciplinary effect, on a firm and its directors and officers. Absent a D\&O insurance policy, a firm or its directors and officers will likely bear significant defense costs, even if the allegations are eventually found to be unsubstantiated. For example, Barrick Gold Corporation (a mining firm in our sample) reported that its D\&O insurer paid annual litigation-related costs of C $\$ 0.96$ million, $\mathrm{C} \$ 4.2$ million, and C\$7.7 million for the period 2006 - 2008 under their D\&O insurance policy. Furthermore, given that lawsuits can take years to resolve, and the fact that there are substantial uncertainties in the resolution process, the expected cost of defense can be very high (especially relative to the fees a director earns for serving on the board). Therefore, if D\&O insurance weakens the incentives of directors and officers by insulating them from the threat of litigation and personal liability, directors and officers protected by D\&O insurance are more likely to make imprudent or empire-building, and hence poor, acquisitions.

The protection afforded by corporate indemnification could make D\&O insurance coverage less of a concern to directors and officers in corporate decision-making. After the 2001 reform of the Canada Business Corporations Act (CBCA) (the federal corporate statute in Canada), a corporation can now indemnify a director or officer for legal expenses regardless of the outcome of the proceeding, as well as for amounts paid to settle or satisfy a judgment in civil, criminal, or administrative proceedings if a director or officer has acted honestly and in good faith, and subject to court approval for defense cost in derivative litigation (Cheffins and Black, 2006). In practice, the courts in Canada apply a "business judgment rule" when assessing whether there has been a breach of duty of care, and this sets a high hurdle for proving a breach of duty of care (Cheffins and Black, 2006, p.1442). Because of this ease of access to indemnification (especially 
after 2001 and, therefore, during our sample period), the effect of D\&O insurance on corporate decisions is an empirical question.

In addition to directly contributing to the understanding of the incentive implications of D\&O insurance, our study is also related to the line of research examining the effects of corporate governance on corporate $\mathrm{M} \& \mathrm{~A}$ decisions and, more broadly, the growing literature on corporate governance. Harford and Li (2007) find that chief executive officers (CEOs) reap personal benefits from making acquisitions even when these acquisitions have poor outcomes for stockholders. Masulis et al. (2007) report that acquirers with more antitakeover provisions, and hence less discipline from the market for corporate control, experience significantly lower announcement-period abnormal stock returns, while Harford, Humphèry, and Powell (2010) show that firms with entrenched managers tend to acquire targets with low synergies. Datta, Iskandar-Datta, and Raman (2001) provide evidence that governance mechanisms (e.g., executive stock options) that effectively align shareholder-manager incentives lead to more profitable acquisition decisions.

We organize the remainder of the paper as follows. In Section 2, we describe the disclosure of D\&O insurance information in Canada, data collection, and the sample. Section 3 describes the key variables and their summary statistics. Section 4 reports and discusses the empirical results. Section 5 concludes. 


\section{Data and sample selection}

We use a sample of Canadian companies listed on the Toronto Stock Exchange (TSX) because Canada legally mandates companies to disclose information concerning D\&O insurance purchases. To keep the manual data collection manageable, we focus on constituent firms of the TSE 300 Index (currently S\&P/TSX Composite Index) for the period $2002-2008$. The TSE 300 Index is the most representative stock index in Canada and its inclusion criteria include firm size and the trading liquidity of the stock. We identify companies that appear at least once in the TSE 300 Index. We then hand-collect D\&O insurance information from the companies' proxy circulars filed in the SEDAR database (available at www.sedar.com). Available information about D\&O insurance includes whether or not a firm has D\&O insurance in a given year, and the personal and corporate coverage indemnity limits, premiums, and deductibles. Personal and corporate indemnity coverage are equal and there is no personal deductible in the majority of cases. A D\&O policy is typically valid for one year and renewable thereafter (subject to mutual agreement). The policy coverage period may not coincide with the reporting fiscal year. In such a case, we take care to map D\&O policies into the corresponding fiscal year by calculating the (time weighted average) amount of coverage limit that is available to the firm's directors and officers throughout the fiscal year. If the proxy circular for a firm-year is not available, we code the D\&O insurance variables as missing.

M\&A data are from Securities Data Corporation's (SDC) Mergers and Acquisitions database. We require that a) the acquirer is a Canadian firm; b) the deal is completed; and c) an acquirer has sufficient (primary issue) stock price data for our event study (200 trading days of stock returns prior to an acquisition announcement). ${ }^{8}$ We obtain stock prices from FactSet. We then match our D\&O insurance sample with the M\&A sample to derive the intersection of 709 deals made by 278 firms. The target firms in these acquisitions are primarily from Canada (55\%), the

\footnotetext{
${ }^{8}$ Occasionally, an acquirer may have more than one announcement on a day and these multiple announcements are excluded for the ease of interpreting the results.
} 
US (27\%), and the UK (3\%). Accounting information is obtained from Compustat - North America. ${ }^{9}$ D\&O insurance and accounting variables are lagged relative to the acquisition announcement date.

In Table 1, we present the distribution of our sample of acquisitions by announcement year. As can be seen from the table, the number of acquisitions per year is quite uniform from 2002 to 2008. Table 1 also presents the annual mean acquirer market value of equity, mean deal size, and mean relative deal size (deal value scaled by acquirer market value of equity). The median relative deal size in our sample (5\%) is comparable to the $6 \%$ reported in Masulis et al. (2007).

[Insert Table 1 here]

\section{Variables and summary statistics}

\subsection{D\&O insurance}

As discussed in Section 2, the data on D\&O insurance are compiled from a sample of Canadian publicly listed firms, which are required to disclose the details of their D\&O insurance policies in their proxy statements. Following the literature (e.g., Core, 1997; Chalmers et al., 2002), we use two proxies for D\&O insurance: (1) an indicator variable (Insurance) for whether the firm has a D\&O insurance policy; (2) a continuous variable (Coverage/market value of equity) defined as the personal coverage limit of the D\&O insurance policy scaled by the firm's average market value of equity in a year. Scaling coverage by the market value of equity is necessary as the market value of equity is in theory a proxy for the maximum liability exposure and both D\&O insurance coverage and damage award are often positively correlated with the market value of equity (Baker and Griffith, 2007). If a firm does not purchase D\&O insurance, the continuous variable is set to zero.

\footnotetext{
${ }^{9}$ As described in the Appendix, some of our accounting variables are winsorized at the $1^{\text {st }} / 99^{\text {th }}$ percentiles.
} 
Table 2 shows the summary statistics of the D\&O insurance variables. About $72 \%$ of the acquirers in our sample purchase $\mathrm{D} \& \mathrm{O}$ insurance policies to protect their directors and officers from financial liability in the event that they are sued because of decisions made on behalf of the firm. The average personal policy limit is $\mathrm{C} \$ 46.5 \mathrm{~mm}$ : this is considerably higher than the average policy limit reported in Chalmers et al. (2002), but firms in our sample of acquirers are also much larger than firms in their sample of IPOs. The mean scaled coverage ratio in our sample is 0.033 .

\subsection{Acquirer abnormal announcement returns}

We examine the effect of $\mathrm{D} \& \mathrm{O}$ insurance coverage on the cumulative abnormal (marketmodel-adjusted) return to the acquirer around the acquisition announcement date. Announcement dates are from SDC's Mergers and Acquisitions database. We use the S\&P/TSX Composite value-weighted index as the market portfolio and estimate the parameters of the market model using returns over the 200-trading-day period from event day -210 to event day -11 (day 0 is the acquisition announcement date). Following the recent literature (e.g., Masulis et al., 2007), we compute and report five-day cumulative abnormal returns (CARs) over the $(-2,+2)$ event window. ${ }^{10}$ As can be seen from Table 2, the average five-day CAR for our sample is $0.628 \%$.

[Insert Table 2 here]

\subsection{Acquisition premiums}

We also examine the effect of $\mathrm{D} \& \mathrm{O}$ insurance coverage on acquisition premiums to explore the potential channels through which managerial legal liability coverage affects acquirer returns.

\footnotetext{
${ }^{10}$ In unreported results, we also compute 11-day cumulative abnormal returns over the $(-5,+5)$ event window and find qualitatively similar results on insurance coverage.
} 
Following the recent literature (e.g., Datta et al., 2001), we define acquisition premiums (Acquisition premium_4w) as the ratio of the offer price to the target's stock price four weeks prior to the initial announcement date minus one. Acquisition premium data are from SDC. Acquisition premiums are expressed in percentage form in Table 2, and the mean acquisition premium (Acquisition premium_4w) for the sample is $38.4 \% .{ }^{11}$ Because a substantial number of the target firms in our sample are privately held (independent firms or subsidiaries), we can only measure the acquisition premiums for about 160 deals.

\subsection{Deal and acquirer characteristics}

We also control for deal-specific characteristics that prior literature has shown to affect acquirer returns (see Masulis et al., 2007, for a comprehensive discussion). Specifically, we control for the method of payment (All cash or Stock), relative deal size, industry relatedness of the acquisition, and target type (Public, Private, and Subsidiary). All cash is an indicator variable which equals one if the acquisition is fully financed with cash, and zero otherwise. Stock is an indicator variable which equals one if the acquisition is financed either partially or fully with stock, and zero otherwise. Relative deal size is defined as the deal value scaled by the bidder's market value of equity on event day -11 . Unrelated deal is an indicator variable which equals one for diversifying acquisitions, and zero otherwise. We classify a deal as a diversifying acquisition if the acquirer and target do not have the same two-digit standard industry classification (SIC) code. Descriptive statistics for all these variables are in Table 2.

In our regressions, we also control for acquirer-specific characteristics such as acquirer size (the natural log of book value of total assets), market-to-book ratio, leverage, free cash flow, and stock price run-up (acquirer's buy-and-hold abnormal return over the 200-trading-day period

${ }^{11}$ As a robustness test, we also follow Wang and Xie (2009) and examine acquisition premiums defined as the ratio of the offer price to the target's stock price one week prior to the initial announcement date minus one (from SDC). Because our empirical results from using this measure of premiums are robust to this alternate definition, we focus on results using the four-week premium in our analyses. 
from event day -210 to -11$)$. All these characteristics have been discussed in the literature as potential determinants of acquirer decisions and outcomes (e.g., Jensen, 1986; Lang, Stulz, and Walkling, 1991; Shleifer and Vishny, 2003; Masulis et al., 2007). Detailed definitions and descriptive statistics of these variables can be found in the Appendix and Table 2.

Because our sample of acquisitions by Canadian acquirers is different from the standard USbased samples used in most of the M\&A literature, in Table 3 we split the sample into groups by payment method, target type, and deal size and compare the mean values of acquirer abnormal announcement returns.

[Insert Table 3 here]

Acquirers experience positive abnormal returns when they pay for their acquisitions with cash $(0.88 \%)$, while they experience negative abnormal returns in stock-financed acquisitions $(-0.15 \%)$. The difference in CARs between these two groups is in the same direction as found in most USbased samples of acquirer returns but is not statistically significant at conventional levels ( $p$-value $=$ 0.12). As in US-based samples of acquisitions, the Canadian acquisitions in our sample tend to be value-increasing for acquirer shareholders when the targets are private or subsidiary firms and value-decreasing for acquirer shareholders when the targets are public firms. The differences in CARs by target type are statistically significant at the $1 \%$ level. Also there is weak evidence that acquirer announcement returns for larger deals are higher.

\subsection{Univariate analysis}

Before conducting regression analysis in the next section, we first take an initial look at univariate statistics to see if there are any broad patterns in the data that are consistent with our hypothesis about the relation between managerial legal liability coverage and acquisition quality. Specifically, we split the sample into groups with and without D\&O insurance and compare the 
mean values of acquirer CARs, acquisition premiums, and a variety of deal characteristics. The results are presented in Table 4.

[Insert Table 4 here]

As can be seen from the table, the means of acquirer CARs and acquisition premiums are consistent with our main hypothesis. Specifically, we find that firms without D\&O insurance coverage tend to have significantly higher acquirer CARs, on average, than do firms with D\&O insurance coverage. For instance, the mean five-day CAR for firms without D\&O insurance is $1.42 \%$, while the mean five-day CAR for firms with D\&O insurance coverage is $0.32 \%$. This difference is statistically significant at the $5 \%$ level. ${ }^{12}$ We also find that firms with D\&O insurance coverage tend to pay higher premiums, on average, to acquire their targets than do firms without $\mathrm{D} \& \mathrm{O}$ insurance. Acquirers in the $\mathrm{D} \& \mathrm{O}$ insurance group pay an average acquisition premium (relative to the target's stock price four weeks before announcement) of $47.6 \%$ while acquirers without D\&O insurance pay an average premium of $22.9 \%$. This difference is also statistically significant at the $5 \%$ level.

Regarding deal characteristics, the results are somewhat mixed. For instance, we find that firms with D\&O insurance are more likely to make unrelated acquisitions than firms without D\&O insurance. Prior literature has demonstrated that unrelated (or diversifying) acquisitions are associated with losses in value for acquirer shareholders (Morck, Shleifer, and Vishny, 1990). However, we also find that firms with D\&O insurance are more likely to make all-cash deals (instead of stock-financed deals) and deals with subsidiary targets, characteristics that are

\footnotetext{
${ }^{12}$ An alternative potential interpretation of this result is that directors of firms without $\mathrm{D} \& \mathrm{O}$ insurance subject potential M\&A deals to greater scrutiny (e.g., a higher internal rate of return (IRR) or net present value (NPV) screen) because the failure of a deal (and associated shareholder litigation) could subject them to significant personal liability. It is, in theory, possible that stricter deal-acceptance thresholds by firms without D\&O insurance are not in the best interests of shareholders because marginal, but still positive NPV, acquisitions might be rejected.
} 
generally associated with positive acquirer abnormal announcement returns in prior literature. Therefore, we will control for these deal characteristics in multivariate regressions to isolate the impact of D\&O insurance coverage on acquisition outcomes.

\section{Empirical results}

\subsection{D\&O insurance and acquirer returns}

In this section we examine the impact of $\mathrm{D} \& \mathrm{O}$ insurance on acquirer cumulative abnormal announcement returns (CARs) using multivariate regressions. The main empirical model is:

$\mathrm{CAR}=f(D \& O$ insurance measures, Deal characteristics, Acquirer characteristics, Industry and time effects).

In Eq. (1), the dependent variable is the acquirer's five-day cumulative abnormal return (CAR ($2,+2)$ ). The independent variables of interest are the $\mathrm{D} \& \mathrm{O}$ insurance measures: the insurance indicator and coverage ratio.

[Insert Table 5 here]

The results from ordinary least square (OLS) regressions of Eq. (1) are presented in Table 5. In columns 1 and 2, the $\mathrm{D} \& \mathrm{O}$ insurance indicator variable is used as the key independent variable, while in columns 3 and 4 we use the continuous variable (coverage ratio) instead. For each set of regressions we run two specifications. The first controls for a set of deal characteristics and year and industry dummies; the second adds controls for acquirer characteristics. As can be seen from the table, the coefficients of $\mathrm{D} \& \mathrm{O}$ insurance measures are negative and statistically significant across all model specifications, suggesting a negative impact 
of $\mathrm{D} \& \mathrm{O}$ insurance coverage on acquirer returns.

More specifically, the point estimates in columns 3 and 4 indicate that a one-standarddeviation increase in the insurance coverage ratio decreases average acquirer CARs by approximately 1.25 to 1.45 percentage points, other things being equal. Hence, the effect of D\&O insurance on acquirer abnormal announcement returns appears both economically and statistically significant.

The coefficients on the control variables are largely consistent with prior literature. Specifically, we find that acquisitions of private and subsidiary targets are associated with higher acquirer returns. We also find that relative deal size is positively associated with acquirer returns, while acquirer size is negatively associated with acquirer returns (column 4).

\subsection{D\&O insurance and acquirer returns: Additional governance controls}

The results in Table 5 are consistent with the notion that managerial legal liability coverage weakens managerial incentives because D\&O insurance insulates directors and officers from potential personal liability and, therefore, aggravates agency problems. This appears to result in lower acquirer shareholder returns. There are, however, other monitoring and governance mechanisms that might attenuate agency conflicts between managers and shareholders. Ignoring these factors potentially creates an omitted-variables problem. In this section, we include a series of firm and industry controls in our model to test the robustness of the results.

Specifically, we include proxy variables for managerial quality, industry competitiveness, managerial ownership, and institutional ownership into the regressions. Intuitively, managerial quality might affect acquisition outcomes. It is also possible that poor-quality managers cause their firms to adopt D\&O insurance as an entrenchment device, suggesting that our D\&O insurance variables might proxy for managerial quality. We therefore follow Morck et al. (1990) and proxy for acquirer managerial quality (Managerial quality) with the acquirer's industryadjusted operating income growth over the two years prior to the acquisition announcement date. 
Following Morck, Stangeland, and Yeung (2000), industry adjustment is based on median operating income growth rate in the industry classified by three-digit SIC codes using all firms in the Compustat - North America database. ${ }^{13}$ This proxy variable has been used in other recent empirical M\&A studies of acquirer announcement returns (e.g., Masulis et al., 2007; Wang and Xie, 2009).

It has long been argued that product market competition plays an important disciplinary role on managerial behavior (Hart, 1983). The absence of product market competition allows managers to relax and enjoy a "quiet life." In contrast, managerial slack is less of a concern in more competitive industries since the margin for error is thin in these industries and poor decisions can be quickly exploited by competitors, jeopardizing firms' survival and managers' job-retention prospects (Shleifer and Vishny, 1997; Scharfstein, 1988; Masulis et al., 2007). Giroud and Mueller (2011) argue that product market competition is a more powerful discipline tool than internal governance mechanisms. Following Masulis et al. (2007), we use two measures to capture industry competitiveness. The first is based on the Herfindahl-Hirschman Index (HHI), calculated as the sum of squared market shares of all Compustat firms in each industry, and higher values indicate greater concentration and lower product market competitiveness. ${ }^{14} \mathrm{We}$ define an industry as competitive (Competitive industry) if the industry's HHI index is in the bottom quartile of all 48 Fama-French industries. The second is based on the industry's median ratio of selling expense to sales, which acts as a proxy for product uniqueness (Unique industry). We define an industry as unique if the industry's median ratio of selling expense to sales is in the top quartile of all 48 Fama-French industries.

Institutional investors also play an important corporate governance role. Institutional

\footnotetext{
${ }^{13}$ Some Canadian firms are not covered by Compustat; however, the US and Canadian economies are broadly similar in most dimensions so that firms from the same industry in the two countries face relatively similar competitive environments (Morck et al., 2000).

${ }^{14}$ Similar measure has been used in other recent studies such as Barth, Lin, Lin, and Song (2009) and Houston, Lin, Lin, and Ma (2010).
} 
investors are better informed and more capable monitors (Shleifer and Vishny, 1997; Grinstein and Michaely, 2005). As a consequence, the presence of institutional investors makes external governance more effective and increases the marginal costs of engaging in empire-building or other types of moral hazard activities (Lin, Ma, and Xuan, 2011). Institutional ownership (Institutional ownership) is the number of shares held by all institutional investors divided by the total number of shares outstanding. Our institutional investor holdings data are obtained from the FactSet/LionShares Global Ownership database. Institutional ownership includes shares held by professional investment managers. ${ }^{15}$ FactSet compiles these data using a variety of sources, including company proxies and annual reports, public filings by institutional investors, mutual fund industry directories, and announcements by national regulatory agencies and stock exchanges, as described in Ferreira and Matos (2008). We also control for insider equity ownership (Insider ownership) because equity ownership can help align the interests of managers with those of shareholders and therefore alleviate the agency problems associated with managerial opportunism (Jensen, 1993). ${ }^{16}$

[Insert Table 6 here]

In Table 6 we present the results from regressions including these new variables. One facet of these regressions worth noting is that the sample size is smaller compared to the similar regressions in Table 5. For example, in the regression in column 1, the sample size drops from 680 (Table 5) to 554 (Table 6), and this drop is attributable to data availability for the additional variables noted above. As can be seen from the table, however, the D\&O insurance variables (indicator and continuous) remain negative and statistically significant across all model

\footnotetext{
${ }^{15}$ Such institutional investors include pension funds, mutual funds, insurance companies, investment advisors, and bank trusts. Please see Ferreira and Matos (2008) for more detailed description.

${ }^{16}$ Some Canadian acquirers have a dual-class share structure. In unreported results, we also include an indicator variable for the existence of a dual-class share structure in our CAR regressions. This indicator variable does not have a statistically significant effect on abnormal announcement returns, and our results on insurance coverage are unchanged.
} 
specifications.

The coefficients on the control variables are generally similar to those in Table 5. Of the additional control variables in Table 6 , the coefficients on our proxies for managerial quality and competitive industry are both positive, but their statistical significance varies. Thus, there is some evidence suggesting that better-quality managers and acquirers in more competitive industries make acquisition decisions that are value-increasing for their shareholders. The other additional control variables in Table 6 do not have statistically significant coefficients. ${ }^{17}$

\subsection{D\&O insurance and acquirer returns: Instrumental variables}

Endogeneity is a concern in any study dealing with the interaction between governance structure and corporate decision-making. Relative to other studies in the literature, this issue might be less of a problem in this context because the primary dependent variable in our tests so far is a short-term market-based measure (i.e., returns). Nevertheless, it is still possible that firms with D\&O insurance have firm-specific characteristics that we have thus far failed to account for and that affect both the decision to obtain D\&O insurance coverage and the quality of acquisition decisions. ${ }^{18}$ Although it is difficult to completely solve the endogeneity problem, in this section we attempt to address this issue using an instrumental variable approach.

Following the recent literature (Adams, Lin, and Zou, 2011; Lin, Ma, Malatesta, and Xuan, 2011), we use the industry average D\&O insurance incidence and median coverage ratio as instruments for the firm's D\&O insurance incidence and coverage ratio, respectively. There are two rationales for using the mean/median industry insurance use as the instrument. First, as

\footnotetext{
${ }^{17}$ We conduct a further robustness test by including in our regressions an indicator variable for large deals. This indicator variable equals one if the relative deal size exceeds the 90th percentile of the sample. We then interact this large-deal indicator variable with the insurance indicator and continuous coverage variables. In unreported results, the coefficient on the interaction term is negative but insignificant, and the coefficients on our insurance variables are unchanged. Therefore, the negative effect of D\&O insurance on CAR does not seem to be driven by large deals.

${ }^{18}$ In other words, it is possible that some D\&O insurance purchases are precautionary, in the sense that entrenched or otherwise poorly governed managers choose to buy D\&O insurance against liability for their empirebuilding acquisition decisions in the future. If this were the case, our evidence suggests that D\&O insurance purchases are a leading indicator for poor future acquisition decisions.
} 
Adams et al. (2011) point out, firms in the same region and/or industry may compete for the same small pool of managerial talent in the local labor market. In order to attract good managers, a firm's managerial compensation package (e.g., including D\&O insurance coverage) may be influenced by the compensation package offered by competitors in the same industry or region. Second, firms in the same industry face similar business risks and business cycles, and the risk of facing shareholder litigation often exhibits industry patterns: for example, high-tech firms may be more likely to be targets of litigation in certain periods than other firms are (Core, 2000). As a result, industry average/median D\&O insurance use will be correlated with a firm's D\&O insurance coverage but is unlikely to directly influence the quality of a firm's acquisitions except through the firm's D\&O insurance plan.

We run two first-stage regressions (not reported, for brevity): one with the D\&O insurance coverage indicator variable as the dependent variable and the other with the D\&O insurance coverage ratio (continuous) as the dependent variable. In the former regression, the key instrumental variable is the industry average of the D\&O insurance indicator variable. In the latter regression, the key instrumental variable (IV) is the industry median D\&O insurance coverage ratio (continuous). In both cases, the first-stage IV regressions include all the control variables from Table 6 . We use the fitted values from these first-stage regressions as explanatory variables in the second-stage regressions in Table 7.

\section{[Insert Table 7 here]}

While the first-stage regression results are not reported, the relevant F-tests of industry average D\&O insurance incidence or the industry median coverage ratio as the excluded instrument are always highly significant ( $p$-values lower than 0.01). We also calculate Shea's (1997) partial $R^{2}$ from the first-stage regressions. These values of $R^{2}$ all well exceed the suggested ("rule of thumb") hurdle of $10 \%$. These tests suggest that our instrument is relevant in explaining the variation of the potentially endogenous regressors. 
As can be seen from the table, the empirical results are robust after the instrumentation. The D\&O insurance measures remain negative and statistically significant across model specifications: our main results do not appear to be driven by, or sensitive to, endogeneity. The coefficients on the control variables in Table 7 are generally consistent with those in previous tables.

\subsection{D\&O insurance and acquirer returns: Serial acquirers}

In our sample, some acquirers make more than one acquisition during the sample period (we call these serial acquirers). Serial acquirers could generate endogeneity in our results because firms that are repeatedly involved in M\&A transactions are likely to have greater exposure to litigation risk and thus have a higher (derived) demand for $\mathrm{D} \& \mathrm{O}$ insurance. Furthermore, measuring acquirer announcement returns can be difficult for serial acquirers because preannouncement market prices may already reflect the value (creation or destruction) expected from repeated acquisitions, and serial acquirers tend to be (or become) conglomerates. Therefore, serial acquirers may have both higher demand for $\mathrm{D} \& \mathrm{O}$ insurance and mechanically lower announcement returns, suggesting that our key finding might reflect an endogenous relation. ${ }^{19}$ To address this concern, we include in the regressions an indicator variable that equals one for firms with more than two deals during the sample period. ${ }^{20}$ The regressions in Tables $5-7$ are repeated with the inclusion of this indicator variable, and in untabulated results the serial acquirer dummy does not enter the regression models significantly and the coefficients on the insurance variables are qualitatively unaffected.

In addition, as a direct way to examine whether our announcement return results hold for nonserial acquirers, we drop deals from the analysis if the acquirer has more than two deals in the sample period. This leaves us with 238 deals by non-serial acquirers, and we replicate the regressions in Table 6 and Table 7 for this sample. The results are reported in Table 8.

\footnotetext{
${ }^{19}$ We thank an anonymous referee for bringing this to our attention.

${ }^{20}$ The number of deals per firm ranges from one to nine and with a mean of 3.7.
} 
[Insert Table 8 here]

In columns $1-2$ we regress $\mathrm{CAR}(-2,+2)(\%)$ on the insurance variables with a full vector of control variables (as in Table 6), while in columns $3-4$ we employ instrumental variables regressions (as described in Table 7). Our conclusions about the effects of D\&O insurance on acquirer announcement returns are qualitatively similar in this sample of non-serial acquirers, suggesting that our findings are not driven by serial acquirers buying D\&O insurance to preempt future litigation.

\subsection{Why are acquirer returns lower for firms with D\&O insurance?}

So far our results suggest that firms with managerial legal liability coverage through D\&O insurance make worse acquisition decisions than firms whose managers are not protected (or are less protected) by such coverage. The lower acquirer announcement returns for firms with D\&O insurance are broadly consistent with two possibilities: (1) entrenched managers with D\&O insurance coverage overpay their targets, potentially because of unfettered hubris or empirebuilding (Roll, 1986). If this is the case, we should be able to observe that acquirers with high D\&O insurance coverage pay higher premiums to acquire their targets than do other types of acquirers; (2) entrenched managers with D\&O insurance coverage choose targets with which the acquiring firms have low (or even negative) synergies (and this is perceived by the market). The lack of synergies could be due to a poor match between the acquirer and target because entrenched managers with D\&O insurance coverage are more interested in empire-building than value creation (Harford et al., 2010). In the next two sections we focus on these two possibilities.

\subsubsection{D\&O insurance and acquisition premiums}

In this section we explore the effect of $\mathrm{D} \& \mathrm{O}$ insurance coverage on acquisition premiums. 
The main regression is:

$$
\begin{gathered}
\text { Acquisition premium }=f(D \& O \text { insurance measures, Deal characteristics, Acquirer } \\
\text { characteristics, Industry and time effects). }
\end{gathered}
$$

In Eq. (2), the dependent variable is the four-week premium (Acquisition premium_4w; in percentage points) described in Section 3.3. Our results are qualitatively similar if we use oneweek premiums instead. As noted in Section 3.3, we can only measure acquisition premiums in deals with publicly traded target firms: as a result, the sample size drops to about 110 observations in this part of the analysis. ${ }^{21}$ The results from OLS regressions of Eq. (2) are presented in columns 1 and 2 in Table 9. In columns 3 and 4, the coefficients are based on IV regressions with a similar instrumental variables approach as discussed in Section 4.3.

\section{[Insert Table 9 here]}

As can be seen from the table, the existence of $\mathrm{D} \& \mathrm{O}$ insurance coverage (indicator variable in columns 1 and 3) exerts a positive, albeit insignificant, effect on acquisition premiums. However, the coefficients on the (continuous) insurance coverage ratio variables are positive and statistically significant at the $1 \%$ level, suggesting that acquirers with higher D\&O insurance coverage ratios tend to pay higher premiums to acquire their targets. The point estimates in

\footnotetext{
${ }^{21}$ Announcement-period abnormal returns are significantly lower for acquirers with $\mathrm{D} \& \mathrm{O}$ insurance coverage in this (smaller) subsample of deals involving publicly traded targets. Specifically, the mean acquirer CAR $(-2,+2)$ in the public-target sample is $-1.6 \%$ for acquirers with $\mathrm{D} \& \mathrm{O}$ insurance and $0.9 \%$ for acquirers without $\mathrm{D} \& \mathrm{O}$ insurance. These means are significantly different from one another with a $p$-value of 0.03 . Furthermore, we repeat our CAR regressions from Table 6 using the public-target sample. Our result that there is a negative relation between the use of D\&O insurance (or the level of coverage of D\&O insurance) and CARs still holds. For brevity, these results are not reported but available from the authors upon request.
} 
columns 2 and 4 imply that a one-standard-deviation increase in the D\&O insurance coverage ratio is associated with $16.4-18.3 \%$ higher acquisition premiums (holding acquirer and deal characteristics constant). The effect of $\mathrm{D} \& \mathrm{O}$ insurance coverage on acquisition premiums appears, therefore, to be both economically and statistically significant.

\subsubsection{D\&O insurance and merger synergies}

In this section we examine whether managers protected by D\&O insurance choose targets with which the acquiring firms have low (or even negative) synergies. Following Harford et al. (2010), we first examine combined bidder and target announcement returns to assess total synergies (value creation) for the deals in our sample. Specifically, we compute five-day combined (acquirer and target) cumulative abnormal announcement returns (CAR $(-2,+2))$ for each deal. To combine the CARs of the acquirer and target, we use weights based on their market values. Again, this analysis requires that the target firm be publicly traded and have required share prices for calculating CARs, resulting in relatively small samples. The results are presented in Panel A, Table 10.

[Insert Table 10 here]

As can be seen from the table, the mean (median) combined CAR for all deals in our sample with publicly traded acquirers and targets is a statistically insignificant $0.63 \%(0.69 \%)$. When we split the sample into firms with or without D\&O insurance coverage, however, differences emerge. The median combined CARs for acquirers with D\&O insurance are lower $(-0.1 \%)$ than those for firms without D\&O insurance (1.3\%), and this difference in combined CARs is statistically significantly different from zero at the $5 \%$ level.

As an alternative test, we split the sample into firms with low or high coverage based on the sample median D\&O insurance coverage ratio. Again, median combined CARs for firms with high D\&O insurance coverage are much lower (-0.4\%) than those for firms with low D\&O 
insurance coverage (1.0\%). The difference in combined CARs between these high- and lowcoverage groups is statistically significantly different from zero at the $5 \%$ level. ${ }^{22}$

Another way to measure synergies in M\&A deals is to examine operating performance after the deal is completed. Fu, Lin, and Officer (2010) argue that examination of post-acquisition operating performance is potentially a more direct metric for synergistic gains or losses and real value-added in acquisitions. We employ two widely used measures of firm operating performance: return on assets (ROA) is defined as net income scaled by the market value of total assets at the beginning of the fiscal year. The market value of total assets is the sum of the market value of equity and the book values of preferred stock and debt. Asset turnover (ATO) is defined as sales scaled by the market value of total assets at the beginning of the fiscal year.

Our first test looks at industry-median-adjusted ("abnormal") operating performance (ROA or ATO) after mergers for acquirers with below-median and above-median D\&O insurance coverage ratio. In pre-merger years, abnormal operating performance is calculated as the weighted average of the acquirer's and the target's performance minus the weighted average of industry-median performance using the acquirer's and the target's industry. The weights are based on the market value of total assets of each firm at the beginning of each year. In postmerger years, abnormal operating performance is the merged firm's performance minus the weighted average of the acquirer's and the target's industry-median performance, with the weights determined by using the market value of total assets of the acquirer and the target at the beginning of year -1 (year 0 is the year in which the merger is completed). Industry adjustments are based on both three-digit and four-digit SIC codes.

\footnotetext{
${ }^{22}$ We also calculate the dollar change in the combined value of the acquiring and target firms as a measure of total merger gains, as in Moeller, Schlingemann, and Stulz (2004, Table 7). The dollar change is calculated by multiplying the combined CAR $(-2,+2)$ by the combined market value of the acquirer and target before the event window. A comparison of the dollar total merger gains between the above-median-coverage and below-mediancoverage groups reveals a similar pattern to that based on the percentage combined abnormal return (in Table 10, Panel A). For example, the median dollar total merger gain for the below-median-coverage group is $+\$ 11.9$ million versus a median of $-\$ 9.9$ million in the above-median-coverage group.
} 
The results are in Panels B and C of Table 10. In Panel B we use ROA as the operating performance measure, and the results indicate a significant worsening of abnormal operating performance after the acquisition for acquirers with high D\&O insurance coverage, and insignificant changes in operating performance for acquirers with low D\&O insurance coverage. Specifically, median abnormal operating performance in years $+1,+2$, and +3 is significantly below the median abnormal operating performance in year -1 for acquirers with high D\&O insurance coverage (last row of the table), but not so for acquirers with low coverage. This pattern holds regardless of the level of SIC code (three- or four-digit) used to define industries.

Similarly, the results in Panel C (using asset turnover as the operating performance measure) suggest that operating performance worsens for firms with high D\&O insurance coverage after acquisitions and improves for acquirers with low coverage. However, the pre-to-post differences in the last row of Panel $\mathrm{C}$ are insignificantly different from zero at conventional levels. We test for changes in abnormal operating performance in a more rigorous fashion in Table 11. We use regressions similar to those in Healy, Palepu, and Ruback (1992), where post-merger three-year median abnormal operating performance (ROA or ATO) is regressed on the combined (acquirer and target) industry-adjusted performance in year $-1 .^{23}$ Industry classification is based on threedigit SIC codes, but the results are insensitive to the use of four-digit SIC codes. Low- and highcoverage are as defined in Table 10. The slope coefficient on pre-acquisition performance captures the correlation in abnormal performance between the pre- and post-merger years. Following Harford et al. (2010), we also include controls for the size and market-to-book of acquirer, the attitude of the deal, and whether the target and acquirer are in the same industry. The intercept measures the average change in the industry-adjusted abnormal performance that is due to the merger, and is our main coefficient of interest.

\section{[Insert Table 11 here]}

\footnotetext{
${ }^{23}$ Our results are robust to using the post-merger five-year median as the dependent variable.
} 
The results in Table 11 are consistent with the conclusions from Table 10. Specifically, the intercepts suggest that high-coverage acquirers appear to suffer significant deteriorations of both ROA and ATO in the three years following merger completion, while low-coverage acquirers do not. Also note that high-coverage acquirers engaging in unrelated deals experience significantly poorer operating performance (measured by ROA).

In untabulated analyses, we also check the robustness of our results to the existence of serial acquirers in our sample (as discussed in Section 4.4). We first include the serial acquirer indicator variable (equal to one for acquirers with more than two deals in our sample, zero otherwise) in Table 9 (acquisition premiums) and Table 11 (change in abnormal operating performance). The coefficient on the serial acquirer indicator variable is only significant in Table 11, column 1, where we find serial acquirers with below-median D\&O coverage appear to have a higher post-merger three-year median abnormal ROA. The intercepts in these regressions (measuring the effect of our insurance variables) are qualitatively unaffected. Second, we limit the analysis in Table 9 (acquisition premiums) and Table 11 (change in abnormal operating performance) to the non-serial-acquirer sample by dropping acquirers with more than two deals in our sample period. The insurance variables still have a positive and statistically significant effect on acquisition premiums. In Table 11, we find low-coverage acquirers appear to experience an improvement in ATO in the three years following merger completion, while highcoverage acquirers do not. Due to concerns about test power in this very small sample of nonserial acquirers with public targets, however, these results are not tabulated. Overall, our main conclusions do not seem to be driven by the existence of serial acquirers in our sample.

In sum, our univariate (Table 10) and multivariate (Table 11) results suggest that synergies, whether measured using combined CARs or abnormal operating performance changes, appear to be significantly lower in mergers involving acquirers with above-median D\&O insurance coverage. We also find that high-coverage acquirers tend to overpay their targets (Table 9). 
These results are suggestive of the cause of the lower acquirer abnormal announcement returns noted earlier: acquirers with high D\&O insurance coverage both overpay and choose targets with which they have low synergies.

\section{Conclusion}

D\&O insurance is extremely common in North America. In principle, D\&O insurance policies protect a firm's directors and officers from litigation brought by shareholders (and other parties) because of decisions made by those directors and officers on behalf of the firm. In practice, suits brought are almost always settled out of court within the D\&O insurance coverage limit. Despite the prevalence and importance of D\&O insurance, there is little empirical research on the effects of D\&O insurance on the incentives of directors and officers, and how those incentives shape corporate decisions.

In this study, we examine the effect of D\&O insurance on the outcomes from a major form of corporate investment: mergers and acquisitions. Using hand-collected D\&O insurance data for Canadian listed companies, we find that acquirers whose managers are protected by D\&O insurance, or carry higher policy limits, experience significantly lower announcement-period abnormal stock returns than do acquirers without D\&O insurance (or those with low policy limits). Further analyses show that there are two channels through which the well-protected managers of firms with high D\&O insurance policy limits make relatively poor M\&A decisions: overpayment for the target and low synergies with the target.

Overall, our results are consistent with the argument that $\mathrm{D} \& \mathrm{O}$ insurance induces unintended moral hazard on the part of directors and officers by shielding them from the discipline of shareholder litigation. Our study complements existing studies (e.g., Masulis et al., 2007) which demonstrate that entrenched, or poorly governed managers who are protected from shareholder discipline make poor decisions about major corporate investments. 
Appendix: Definition of variables

\begin{tabular}{ll}
\hline Variables & Definitions \\
\hline
\end{tabular}

Insurance information

Insurance (1/0)

Insurance coverage

Insurance coverage ratio

Equals one if a firm has D\&O insurance in the fiscal year before the acquisition announcement year; zero otherwise

The coverage limit on the personal coverage portion of the $\mathrm{D} \& \mathrm{O}$ insurance policy in $\mathrm{C} \$ \mathrm{~mm}$

Limit on the personal coverage portion of the D\&O insurance policy/ market value of stock (averaged on the monthly basis in the reporting year)

Cumulative abnormal returns (CAR)

CAR $(-2,+2)(\%)$

Five-day cumulative abnormal return calculated using a market model estimated over the period $[-210,-11]$ relative to the announcement date (day 0 )

\section{Deal characteristics}

Private target $(1 / 0)$

Subsidiary target $(1 / 0)$

All-cash deal (1/0)

Stock deal (1/0)

Friendly deal (1/0)

Unrelated deal (1/0)

Relative size

Acquisition premium_4w (\%)

Equals one when the target is a private firm; zero otherwise

Equals one when the target is a subsidiary; zero otherwise

Equals one for solely cash-financed deals; zero otherwise

Equals one for deals that are at least partially financed by stock; zero otherwise

Equals one for friendly deals; zero otherwise

Equals one for deals in which the acquirer and the target do not have the same two-digit SIC industry; zero otherwise

SDC deal value/acquirer market value on the $11^{\text {th }}$ trading day before the deal announcement date, winsorized at the $1^{\text {st }} / 99^{\text {th }}$ percentiles

$(($ Offer price/Target stock price 4 weeks prior to announcement $)-1) \times 100$

\section{Acquirer characteristics}

$\log ($ assets)

Natural log of book value of total assets in the fiscal year prior to announcement

Market-to-book

(Fiscal-year-end market value of equity + book value of liabilities)/total assets in the fiscal year prior to announcement, winsorized at the $1^{\text {st }} / 99^{\text {th }}$ percentiles

Leverage

(Long-term debt + debt in current liabilities)/(fiscal-year-end market value of equity + book value of liabilities) in the fiscal year prior to announcement

Free cash flow (Operating income before depreciation - interest expense - income taxes - 
capital expenditure)/book value of total assets in the fiscal year prior to announcement, winsorized at the $1^{\text {st }} / 99^{\text {th }}$ percentiles

Stock price run-up (\%)

Competitive industry (1/0)

Unique industry (1/0)

Insider ownership (\%)

Institutional ownership (\%)

Managerial quality
Acquirer's buy-and-hold return during the $[-210,-11]$ window minus the buyand-hold return for the TSE 300Index over the same period, winsorized at the $1^{\text {st }} / 99^{\text {th }}$ percentiles

Equals one if the acquirer's industry is in the bottom quartile of Fama-French 48 industries' Herfindal-Hirschman Index in the year prior to announcement; zero otherwise

Equals one if the acquirer's industry is in the top quartile of Fama-French 48 industries' median selling expense scaled by sales in the year prior to announcement; zero otherwise

The proportion of shares held by company insiders

The proportion of shares held by institutional investors

Proxied by average annual industry-median-adjusted operating income (i.e., earnings before interest, tax, and depreciation) growth rate over the previous two years (see Morck et al., 1990). Industry adjustment is based on three-digit SIC codes, and the adjusted growth rate is winsorized at the $1^{\text {st }} / 99^{\text {th }}$ percentiles. 


\section{References}

Adams, M., Lin, C., Zou, H., 2011. Chief executive officer incentives, monitoring, and corporate risk management: Evidence from insurance use. Journal of Risk and Insurance, forthcoming.

Baker, T., Griffith, S.J., 2007. Predicting corporate governance risk: Evidence from the directors' \& officers' liability insurance market. The University of Chicago Law Review 74, 487-544.

Barth, J., Lin, C., Lin, P., Song, M., 2009. Corruption in bank lending to firms: Cross-country micro evidence on the beneficial role of competition and information sharing. Journal of Financial Economics 91, 361-388.

Bhagat, S., Brickley, J., Coles, J., 1987. Managerial indemnification and liability insurance: The effect on shareholder wealth. Journal of Risk and Insurance 54, 721-736.

Black, B., Cheffins, B., Klausner, M., 2006. Outside director liability. Stanford Law Review 58, $1055-1160$.

Boyer, M., 2005. Directors' and officers' insurance and shareholder protection. Unpublished working paper, HEC-Montreal University.

Chalmers, J., Dann, L., Harford, J., 2002. Managerial opportunism? Evidence from directors' and officers' insurance purchases. Journal of Finance 57, 609-636.

Cheffins, B., Black, B., 2006. Outside director liability across countries. Texas Law Review 84, $1385-1480$.

Chung, H., Wynn, J., 2008. Managerial legal liability coverage and earnings conservatism. Journal of Accounting and Economics 46, 135-153.

Core, J., 1997. On the corporate demand for directors' and officers' insurance. Journal of Risk and Insurance 64, 63-87.

Core, J., 2000. The directors' and officers' insurance premium: An outside assessment of the quality of corporate governance. Journal of Law, Economics, \& Organization 16, 449-477.

Cox, J., 1997. Making securities fraud class actions virtuous. Arizona Law Review 39, 49-524.

Datta, S., Iskandar-Datta, M., Raman, K., 2001. Executive compensation and corporate acquisition decisions. Journal of Finance 56, 2299-2336.

Ferreira, M., Matos, P., 2008. The colors of investor's money: The role of institutional investors around the world? Journal of Financial Economics 88, 499-533.

Fu, F., Lin, L., Officer, M., 2010. Acquisitions driven by stock overvaluation: Are they good deals? Unpublished working paper, Singapore Management University and Loyola Marymount University.

Gillan, S., Panasian, C., 2010a. Reassessing what matters in corporate governance: Evidence from the market for directors' and officers' liability insurance. Unpublished working paper, Texas Tech University.

Gillan, S., Panasian, C., 2010b. Cross-listing, litigation risk, and insurance. Unpublished working paper, Texas Tech University.

Giroud, X., Mueller, H., 2011. Corporate governance, product market competition, and equity prices. Journal of Finance 66, 563-600.

Gong, G., Louis, H., Sun, A., 2008. Earnings management, lawsuits, and stock-for-stock acquirers' market performance. Journal of Accounting and Economics 46, 62-77.

Grinstein, Y., Michaely, R., 2005. Institutional holdings and payout policy. Journal of Finance $60,1389-1426$.

Harford, J., Li, K., 2007. Decoupling CEO wealth and firm performance: The case of acquiring CEOs. Journal of Finance 62, 917-949. 
Harford, J., Humphèry, M., Powell, R., 2010. The sources of value destruction in acquisitions by entrenched managers. Unpublished working paper, University of Washington.

Hart, O., 1983. The market mechanism as an incentive scheme, The Bell Journal of Economics 14, 366-382.

Healy, P., Palepu, K., Ruback, R., 1992. Does corporate performance improve after mergers? Journal of Financial Economics 31, 135-175.

Holderness, C., 1990. Liability insurers as corporate monitors. International Review of Law and Economics 10, 115-129.

Houston, J., Lin, C., Lin, P., Ma, Y., 2010. Creditor rights, information sharing and bank risk taking, Journal of Financial Economics 96, 485-512.

Jensen, M., 1986. The agency costs of free cash flow: Corporate finance and takeovers. American Economic Review 76, 323-329.

Jensen, M., 1993. The modern industrial revolution, exit, and the failure of internal control systems. Journal of Finance 48, 831-880.

Lang, L., Stulz, R., Walkling, R., 1991. A test of the free cash flow hypothesis: The case of bidder returns. Journal of Financial Economics 29, 315-336.

Lin, C., Ma, Y., Xuan, Y., 2011. Ownership structure and financial constraints: Evidence from a structural estimation. Journal of Financial Economics, forthcoming.

Lin, C., Ma, Y., Malatesta, P., Xuan, Y., 2011. Ownership structure and the cost of corporate borrowing. Journal of Financial Economics 100, 1-23.

Masulis, R., Wang, C., Xie, F., 2007. Corporate governance and acquirer returns. Journal of Finance 62, 1851-1889.

Mayers, D., Smith, C., 1982. On the corporate demand for insurance. Journal of Business 55, 281-296.

Moeller, S., Schlingemann, F., Stulz, R., 2004. Firm size and the gains from acquisitions. Journal of Financial Economics 73, 201-228.

Morck, R., Shleifer, A., Vishny, R., 1990. Do managerial objectives drive bad acquisitions? Journal of Finance 45, 31-48.

Morck, R., Stangeland, D., Yeung, B., 2000. Inherited wealth, corporate control, and economic growth. In: Morck, R. (Ed.), Concentrated Corporate Ownership, University of Chicago Press, 319-369.

Roll, R., 1986. The hubris hypothesis of corporate takeovers. Journal of Business 59, 197-216.

Scharfstein, D., 1988. Product market competition and managerial slack. RAND Journal of Economics 19, 147-155.

Seligman, J., 2004. Rethinking private securities litigation. University of Cincinnati Law Review 73, 95-138.

Shea, J., 1997. Instrument relevance in multivariate linear models: A simple measure. Review of Economics and Statistics 79, 348-352.

Shleifer, A., Vishny, R., 1997. A survey of corporate governance. Journal of Finance 52, $737-$ 783.

Shleifer, A., Vishny, R., 2003. Stock market driven acquisitions. Journal of Financial Economics 70, 295-311.

Stern, L., Boyer, M., 2010. Is corporate governance risk valued? Evidence from directors' and officers' insurance. Unpublished working paper, Ohio State University and HEC Montreal University. 
Thompson, R., Thomas, R., 2004. The new look of shareholder litigation: Acquisition-oriented class actions. Vanderbilt Law Review 57, 131-209.

Tillinghast-Towers Perrin, 2002. Directors and officer liability survey, US and Canadian results 2001.

Wang, C., Xie, F., 2009. Corporate governance transfer and synergistic gains from mergers and acquisitions. Review of Financial Studies 22, 829-858.

Weiss, E., White, L., 2004. File early, then free ride: How Delaware law (mis)shapes shareholder class actions. Vanderbilt Law Review 57, 1795-1881.

Wynn, J., 2008. Legal liability coverage and voluntary disclosure. Accounting Review 83, 16391669.

Zou, H., Wong, S., Shum, C., Xiong, J., Yan, J., 2008. Controlling-minority shareholder incentive conflicts and directors' and officers' liability insurance: Evidence from China. Journal of Banking \& Finance 32, 2632-2645.

Zou, H., Adams, M., 2008. Debt capacity, cost of debt, and corporate insurance. Journal of Financial and Quantitative Analysis 43, 433-466. 
Table 1

Acquisitions by announcement year

The sample comprises 709 completed mergers and acquisitions made by firms that appeared in the TSE 300 Index between 2002 and 2008, subject to the availability of D\&O insurance and stock price information. The numbers in parentheses are medians. C $\$ \mathrm{~mm}$ is millions of Canadian dollars. Absolute dollar values are expressed in real terms (2002 Canadian dollars). Relative size is defined in the Appendix.

\begin{tabular}{|c|c|c|c|c|c|}
\hline Year & $\begin{array}{c}\text { No. of } \\
\text { acquisitions }\end{array}$ & $\begin{array}{l}\text { Percentage of } \\
\text { sample }\end{array}$ & $\begin{array}{c}\text { Mean acquirer market } \\
\text { value of equity (C\$mm) } \\
\text { (Median) }\end{array}$ & $\begin{array}{l}\text { Mean deal value } \\
\text { (C\$mm) } \\
\text { (Median) }\end{array}$ & $\begin{array}{c}\text { Mean relative size } \\
\text { (Median) }\end{array}$ \\
\hline 2002 & 102 & 14.4 & $\begin{array}{l}2,718 \\
(637)\end{array}$ & $\begin{array}{c}83 \\
(37)\end{array}$ & $\begin{array}{c}0.17 \\
(0.04)\end{array}$ \\
\hline 2003 & 86 & 12.1 & $\begin{array}{l}2,795 \\
(760)\end{array}$ & $\begin{array}{l}102 \\
(49)\end{array}$ & $\begin{array}{c}0.15 \\
(0.04)\end{array}$ \\
\hline 2004 & 106 & 15.0 & $\begin{array}{l}2,292 \\
(713)\end{array}$ & $\begin{array}{l}150 \\
(74)\end{array}$ & $\begin{array}{c}0.24 \\
(0.10)\end{array}$ \\
\hline 2005 & 108 & 15.2 & $\begin{array}{l}2,993 \\
(973)\end{array}$ & $\begin{array}{l}119 \\
(65)\end{array}$ & $\begin{array}{c}0.14 \\
(0.06)\end{array}$ \\
\hline 2006 & 97 & 13.7 & $\begin{array}{l}4,492 \\
(936)\end{array}$ & $\begin{array}{r}146 \\
(51)\end{array}$ & $\begin{array}{c}0.16 \\
(0.04)\end{array}$ \\
\hline 2007 & 118 & 16.6 & $\begin{array}{c}5,442 \\
(1,249)\end{array}$ & $\begin{array}{l}159 \\
(91)\end{array}$ & $\begin{array}{c}0.11 \\
(0.05)\end{array}$ \\
\hline 2008 & 92 & 13.0 & $\begin{array}{c}5,174 \\
(1,541)\end{array}$ & $\begin{array}{l}116 \\
(58)\end{array}$ & $\begin{array}{c}0.08 \\
(0.03)\end{array}$ \\
\hline Total & 709 & 100.0 & $\begin{array}{l}3,736 \\
(952)\end{array}$ & $\begin{array}{l}126 \\
(58)\end{array}$ & $\begin{array}{c}0.15 \\
(0.05)\end{array}$ \\
\hline
\end{tabular}


Table 2

Summary statistics

This table presents summary statistics for the variables used in our analysis. The sample comprises 709 completed mergers and acquisitions made by firms that appeared in the TSE 300 Index between 2002 and 2008, subject to the availability of D\&O insurance and stock price information. Variable definitions are in the Appendix.

\begin{tabular}{|c|c|c|c|c|c|c|}
\hline \multirow[b]{2}{*}{ Variable } & \multirow[b]{2}{*}{ Mean } & \multirow[b]{2}{*}{ Std. dev } & \multicolumn{3}{|c|}{ Percentiles } & \multirow[b]{2}{*}{$N$} \\
\hline & & & $25^{\text {th }}$ & $50^{\text {th }}$ & $75^{\text {th }}$ & \\
\hline \multicolumn{7}{|l|}{ D\&O insurance } \\
\hline Insurance $(1 / 0)$ & 0.719 & 0.450 & 0.000 & 1.000 & 1.000 & 709 \\
\hline Insurance coverage ( $\mathrm{C} \$ \mathrm{~mm})$ & 46.486 & 76.560 & 0.000 & 20.000 & 50.000 & 677 \\
\hline Insurance coverage ratio & 0.033 & 0.0622 & 0.000 & 0.014 & 0.036 & 675 \\
\hline \multicolumn{7}{|c|}{ Acquirer cumulative abnormal announcement return } \\
\hline $\operatorname{CAR}(-2,+2)(\%)$ & 0.628 & 6.725 & -2.408 & 0.328 & 3.375 & 709 \\
\hline \multicolumn{7}{|l|}{ Acquisition premiums } \\
\hline Acquisition premium_4w $(\%)$ & 38.390 & 67.783 & 12.610 & 28.080 & 49.570 & 158 \\
\hline \multicolumn{7}{|l|}{ Deal characteristics } \\
\hline All-cash deal (1/0) & 0.599 & 0.490 & 0.000 & 1.000 & 1.000 & 709 \\
\hline Stock deal $(1 / 0)$ & 0.221 & 0.416 & 0.000 & 0.000 & 0.000 & 709 \\
\hline Friendly deal (1/0) & 0.977 & 0.148 & 1.000 & 1.000 & 1.000 & 709 \\
\hline Relative size & 0.156 & 0.281 & 0.016 & 0.053 & 0.157 & 680 \\
\hline Unrelated deal (1/0) & 0.405 & 0.491 & 0.000 & 0.000 & 1.000 & 709 \\
\hline Private target $(1 / 0)$ & 0.370 & 0.483 & 0.000 & 0.000 & 1.000 & 709 \\
\hline Subsidiary target $(1 / 0)$ & 0.355 & 0.479 & 0.000 & 0.000 & 1.000 & 709 \\
\hline \multicolumn{7}{|l|}{ Acquirer characteristics } \\
\hline $\log ($ assets $)$ & 7.166 & 1.865 & 6.031 & 6.952 & 7.972 & 708 \\
\hline Market-to-book & 1.762 & 1.014 & 1.191 & 1.431 & 2.002 & 694 \\
\hline Leverage & 0.209 & 0.193 & 0.058 & 0.149 & 0.322 & 693 \\
\hline Stock price run-up (\%) & 5.203 & 50.962 & -17.016 & -1.222 & 16.010 & 709 \\
\hline Free cash flow & -0.002 & 0.135 & -0.029 & 0.027 & 0.068 & 654 \\
\hline Competitive industry (1/0) & 0.128 & 0.335 & 0.000 & 0.000 & 0.000 & 709 \\
\hline Unique industry $(1 / 0)$ & 0.123 & 0.328 & 0.000 & 0.000 & 0.000 & 709 \\
\hline Insider ownership (\%) & 9.314 & 15.135 & 0.201 & 2.414 & 11.306 & 553 \\
\hline Institutional ownership (\%) & 35.365 & 20.508 & 18.874 & 34.503 & 47.926 & 555 \\
\hline Managerial quality & 0.156 & 0.656 & -0.066 & 0.056 & 0.301 & 590 \\
\hline
\end{tabular}


Table 3

Acquirer abnormal announcement returns and deal types

This table compares average acquirer abnormal announcement returns (CAR $(-2,+2)(\%))$ between subsamples based on deal characteristics. A deal is classified as a small (large) deal if the relative size is below (above) the sample median. $p$-values are from two-tailed $t$-tests. The test of difference under target type is private vs. public and subsidiary vs. public, respectively. ${ }^{*},{ }^{* *},{ }^{* * *}$ : statistically significantly different from zero at the $0.10,0.05$, and 0.01 level, respectively. Variable definitions are in the Appendix.

\begin{tabular}{lcccc}
\hline & $N$ & Mean (\%) & Difference (\%) & $p$-value \\
\hline $\begin{array}{l}\text { Payment method } \\
\quad \text { All-cash deals }\end{array}$ & 425 & 0.882 & 1.030 & 0.12 \\
Stock deals & 157 & -0.148 & & \\
& & & & \\
Target type & 178 & -0.721 & & 0.01 \\
$\quad$ Deals targeting a public firm & 262 & 1.147 & $1.868^{* * *}$ & 0.01 \\
$\quad$ Deals targeting a private firm & 252 & 1.152 & $1.873^{* * *}$ & \\
Deals targeting a subsidiary & & & & 0.09 \\
& & & & \\
Relative size & 340 & 0.366 & $-0.871^{*}$ & \\
$\quad$ Small deals & 340 & 1.237 & & \\
Large deals & & & & \\
\hline
\end{tabular}


Table 4

Acquirer abnormal announcement returns, acquisition premiums, and deal characteristics

This table reports averages of acquirer abnormal announcement returns, acquisition premiums, and deal characteristics for subsamples based on D\&O insurance use. $p$-values are from two-tailed $t$-tests. ${ }^{*},{ }^{* *},{ }^{* * *}$ : statistically significantly different from zero at the $0.10,0.05$, and 0.01 level, respectively. Variable definitions are in the Appendix.

\begin{tabular}{|c|c|c|c|c|c|c|}
\hline \multirow[b]{2}{*}{ Variable } & \multicolumn{2}{|c|}{ Firms without D\&O insurance } & \multicolumn{2}{|c|}{ Firms with $\mathrm{D} \& \mathrm{O}$ insurance } & \multirow[b]{2}{*}{ Difference } & \multirow[b]{2}{*}{$p$-value } \\
\hline & Mean & $N$ & Mean & $N$ & & \\
\hline \multicolumn{7}{|c|}{ Acquirer cumulative abnormal announcement return } \\
\hline $\operatorname{CAR}(-2,+2)(\%)$ & 1.416 & 199 & 0.320 & 510 & $1.096 * *$ & 0.05 \\
\hline \multicolumn{7}{|l|}{ Acquisition premiums } \\
\hline Acquisition premium_4w (\%) & 22.941 & 59 & 47.597 & 99 & $-24.656 * *$ & 0.03 \\
\hline \multicolumn{7}{|l|}{ Deal characteristics } \\
\hline All-cash deal (1/0) & 0.513 & 199 & 0.633 & 510 & $-0.120 * * *$ & 0.00 \\
\hline Stock deal $(1 / 0)$ & 0.286 & 199 & 0.196 & 510 & $0.090 * * *$ & 0.01 \\
\hline Relative size & 0.237 & 189 & 0.121 & 491 & $0.116^{* * *}$ & 0.00 \\
\hline Unrelated deal $(1 / 0)$ & 0.261 & 199 & 0.461 & 510 & $-0.200 * * *$ & 0.00 \\
\hline Private target $(1 / 0)$ & 0.392 & 199 & 0.361 & 510 & 0.031 & 0.44 \\
\hline Subsidiary target $(1 / 0)$ & 0.271 & 199 & 0.388 & 510 & $-0.117 * * *$ & 0.00 \\
\hline
\end{tabular}


Table 5

Acquirer abnormal announcement returns and D\&O insurance

This table shows the results from OLS regressions of CAR $(2,+2)(\%)$ on measures of D\&O insurance use. Standard errors (clustered at the acquirer level) that are robust to both cross-sectional heteroskedasticity and within-firm serial correlation are used in computing $t$-statistics (in brackets). ${ }^{*}, * *, * * *$ : statistically significantly different from zero at the $0.10,0.05$, and 0.01 level (two-tailed), respectively. The coefficients of the constant, year, and industry dummies are omitted for brevity. Variable definitions are in the Appendix.

\begin{tabular}{|c|c|c|c|c|}
\hline & $(1)$ & $(2)$ & $(3)$ & (4) \\
\hline \multirow[t]{2}{*}{ Insurance $(1 / 0)$} & $-1.679 * *$ & $-2.069 * *$ & & \\
\hline & {$[-2.225]$} & {$[-2.413]$} & & \\
\hline \multirow[t]{2}{*}{ Insurance coverage ratio } & & & $-20.237 * * *$ & $-23.298 * * *$ \\
\hline & & & {$[-2.765]$} & {$[-2.872]$} \\
\hline \multirow[t]{2}{*}{ All-cash deal (1/0) } & -0.053 & 0.014 & 0.015 & 0.286 \\
\hline & {$[-0.089]$} & {$[0.020]$} & {$[0.024]$} & {$[0.405]$} \\
\hline \multirow[t]{2}{*}{ Stock deal $(1 / 0)$} & 0.055 & 0.174 & 0.241 & 0.315 \\
\hline & {$[0.064]$} & {$[0.187]$} & {$[0.265]$} & {$[0.325]$} \\
\hline \multirow[t]{2}{*}{ Friendly deal (1/0) } & -1.062 & -0.614 & -1.004 & -0.622 \\
\hline & {$[-0.975]$} & {$[-0.546]$} & {$[-0.908]$} & {$[-0.538]$} \\
\hline \multirow[t]{2}{*}{ Relative size } & $3.031 * *$ & $2.807^{*}$ & $4.333 * * *$ & $3.745 * *$ \\
\hline & {$[2.187]$} & {$[1.740]$} & {$[3.342]$} & {$[2.411]$} \\
\hline \multirow[t]{2}{*}{ Unrelated deal (1/0) } & 0.085 & 0.440 & 0.058 & 0.514 \\
\hline & {$[0.161]$} & {$[0.744]$} & [0.109] & [0.841] \\
\hline \multirow[t]{2}{*}{ Private target $(1 / 0)$} & $1.431 * *$ & $1.344^{*}$ & $1.859 * *$ & $1.585^{*}$ \\
\hline & {$[1.972]$} & {$[1.706]$} & {$[2.363]$} & {$[1.905]$} \\
\hline \multirow[t]{2}{*}{ Subsidiary target (1/0) } & $1.425 * *$ & $1.633^{* *}$ & $1.600 * *$ & $1.718 * *$ \\
\hline & {$[1.986]$} & [2.129] & {$[2.143]$} & {$[2.167]$} \\
\hline \multirow[t]{2}{*}{$\log$ (assets) } & & -0.003 & & $-0.372 *$ \\
\hline & & {$[-0.016]$} & & {$[-1.694]$} \\
\hline \multirow[t]{2}{*}{ Market-to-book } & & -0.331 & & -0.542 \\
\hline & & {$[-0.925]$} & & {$[-1.414]$} \\
\hline \multirow[t]{2}{*}{ Leverage } & & -2.968 & & -1.518 \\
\hline & & {$[-1.396]$} & & {$[-0.703]$} \\
\hline \multirow[t]{2}{*}{ Stock price run-up (\%) } & & -0.026 & & -0.186 \\
\hline & & {$[-0.041]$} & & {$[-0.296]$} \\
\hline \multirow[t]{2}{*}{ Free cash flow } & & 1.966 & & 1.563 \\
\hline & & {$[0.881]$} & & {$[0.667]$} \\
\hline Year fixed-effects & Yes & Yes & Yes & Yes \\
\hline Industry fixed-effects & Yes & Yes & Yes & Yes \\
\hline Adjusted $R^{2}$ & 0.077 & 0.088 & 0.101 & 0.115 \\
\hline Number of observations & 680 & 613 & 647 & 580 \\
\hline
\end{tabular}


Table 6

Acquirer abnormal announcement returns and D\&O insurance with governance controls

This table shows the results from OLS regressions of CAR(-2, +2)(\%) on measures of D\&O insurance use, controlling for managerial quality (proxied by industry-adjusted two-year growth rate in operating income), product market competition, and insider and institutional ownership. Standard errors (clustered at the acquirer level) that are robust to both cross-sectional heteroskedasticity and within-firm serial correlation are used in computing $t$-statistics (in brackets). ${ }^{*}, * *, * *$ : statistically significantly different from zero at the $0.10,0.05$, and 0.01 level (two-tailed), respectively. The coefficients of the constant, year, and industry dummies are omitted for brevity. Variable definitions are in the Appendix.

\begin{tabular}{|c|c|c|c|c|}
\hline & (1) & $(2)$ & (3) & (4) \\
\hline Insurance $(1 / 0)$ & $\begin{array}{c}-2.644 * * * \\
{[-2.742]}\end{array}$ & $\begin{array}{c}-3.009 * * * \\
{[-2.732]}\end{array}$ & & \\
\hline Insurance coverage ratio & & & $\begin{array}{c}-25.754 * * * \\
{[-3.113]}\end{array}$ & $\begin{array}{c}-33.132 * * * \\
{[-3.561]}\end{array}$ \\
\hline All-cash deal $(1 / 0)$ & $\begin{array}{c}-0.052 \\
{[-0.070]}\end{array}$ & $\begin{array}{c}-0.838 \\
{[-0.942]}\end{array}$ & $\begin{array}{c}0.239 \\
{[0.318]}\end{array}$ & $\begin{array}{c}-0.531 \\
{[-0.589]}\end{array}$ \\
\hline Stock deal $(1 / 0)$ & $\begin{array}{c}-0.126 \\
{[-0.137]}\end{array}$ & $\begin{array}{c}-0.335 \\
{[-0.305]}\end{array}$ & $\begin{array}{c}-0.027 \\
{[-0.028]}\end{array}$ & $\begin{array}{c}-0.147 \\
{[-0.130]}\end{array}$ \\
\hline Friendly deal (1/0) & $\begin{array}{c}-0.355 \\
{[-0.301]}\end{array}$ & $\begin{array}{c}0.395 \\
{[0.317]}\end{array}$ & $\begin{array}{c}-0.451 \\
{[-0.372]}\end{array}$ & $\begin{array}{c}0.231 \\
{[0.174]}\end{array}$ \\
\hline Relative size & $\begin{array}{c}2.338 \\
{[1.220]}\end{array}$ & $\begin{array}{c}1.807 \\
{[0.848]}\end{array}$ & $\begin{array}{c}3.677 * * \\
{[1.979]}\end{array}$ & $\begin{array}{c}3.982 * * \\
{[1.984]}\end{array}$ \\
\hline Unrelated deal $(1 / 0)$ & $\begin{array}{c}0.410 \\
{[0.645]}\end{array}$ & $\begin{array}{c}0.719 \\
{[1.009]}\end{array}$ & $\begin{array}{c}0.469 \\
{[0.724]}\end{array}$ & $\begin{array}{c}0.800 \\
{[1.094]}\end{array}$ \\
\hline Private target $(1 / 0)$ & $\begin{array}{l}1.741 * * \\
{[2.043]}\end{array}$ & $\begin{array}{c}1.251 \\
{[1.243]}\end{array}$ & $\begin{array}{l}1.989 * * \\
{[2.202]}\end{array}$ & $\begin{array}{c}1.736 \\
{[1.612]}\end{array}$ \\
\hline Subsidiary target (1/0) & $\begin{array}{l}1.856^{* *} \\
{[2.286]}\end{array}$ & $\begin{array}{l}1.632^{*} \\
{[1.843]}\end{array}$ & $\begin{array}{l}1.930^{* *} \\
{[2.304]}\end{array}$ & $\begin{array}{c}1.767^{*} \\
{[1.910]}\end{array}$ \\
\hline Log(assets) & $\begin{array}{c}-0.102 \\
{[-0.452]}\end{array}$ & $\begin{array}{c}-0.371 \\
{[-1.373]}\end{array}$ & $\begin{array}{c}-0.505 * * \\
{[-2.125]}\end{array}$ & $\begin{array}{c}-0.898 * * * \\
{[-3.115]}\end{array}$ \\
\hline Market-to-book & $\begin{array}{c}-0.373 \\
{[-0.975]}\end{array}$ & $\begin{array}{c}-0.458 \\
{[-1.065]}\end{array}$ & $\begin{array}{c}-0.613 \\
{[-1.496]}\end{array}$ & $\begin{array}{c}-0.725 \\
{[-1.540]}\end{array}$ \\
\hline Leverage & $\begin{array}{c}-2.814 \\
{[-1.240]}\end{array}$ & $\begin{array}{c}-3.645 \\
{[-1.513]}\end{array}$ & $\begin{array}{c}-1.301 \\
{[-0.568]}\end{array}$ & $\begin{array}{c}-1.958 \\
{[-0.811]}\end{array}$ \\
\hline Stock price run-up (\%) & $\begin{array}{c}-0.002 \\
{[-0.272]}\end{array}$ & $\begin{array}{c}-0.001 \\
{[-0.069]}\end{array}$ & $\begin{array}{c}-0.004 \\
{[-0.477]}\end{array}$ & $\begin{array}{c}-0.004 \\
{[-0.419]}\end{array}$ \\
\hline Free cash flow & $\begin{array}{c}1.816 \\
{[0.631]}\end{array}$ & $\begin{array}{c}4.573 \\
{[1.318]}\end{array}$ & $\begin{array}{c}1.185 \\
{[0.406]}\end{array}$ & $\begin{array}{c}4.394 \\
{[1.275]}\end{array}$ \\
\hline Managerial quality & $\begin{array}{c}0.633 \\
{[1.251]}\end{array}$ & $\begin{array}{l}1.279 * * \\
{[2.366]}\end{array}$ & $\begin{array}{c}0.489 \\
{[0.951]}\end{array}$ & $\begin{array}{l}1.200^{* *} \\
{[2.249]}\end{array}$ \\
\hline Competitive industry $(1 / 0)$ & & $\begin{array}{c}2.602 \\
{[1.545]}\end{array}$ & & $\begin{array}{l}3.174 * \\
{[1.818]}\end{array}$ \\
\hline Unique industry $(1 / 0)$ & & $\begin{array}{c}-1.872 \\
{[-1.314]}\end{array}$ & & $\begin{array}{c}-1.467 \\
{[-0.935]}\end{array}$ \\
\hline Insider ownership (\%) & & $\begin{array}{c}0.011 \\
{[0.369]}\end{array}$ & & $\begin{array}{c}0.031 \\
{[1.174]}\end{array}$ \\
\hline Institutional ownership (\%) & & $\begin{array}{c}0.014 \\
{[0.689]}\end{array}$ & & $\begin{array}{c}0.014 \\
{[0.680]}\end{array}$ \\
\hline Year fixed-effects & Yes & Yes & Yes & Yes \\
\hline Industry fixed-effects & Yes & Yes & Yes & Yes \\
\hline Adjusted $R^{2}$ & 0.103 & 0.140 & 0.131 & 0.188 \\
\hline Number of observations & 554 & 437 & 530 & 416 \\
\hline
\end{tabular}


Table 7

Acquirer abnormal announcement returns and D\&O insurance: Instrumental variable regressions

This table shows the second-stage regression results from regressing CAR $(-2,+2)(\%)$ on instruments for D\&O insurance use. The insurance indicator (coverage) is instrumented with fitted values from a first-stage regression on industry mean (median) insurance incidence (coverage) based on three-digit SIC codes and the control variables. Shea's (1997) partial $R^{2}$ is a measure of IV relevance. First-stage F-test is the test of excluded IV in the first-stage regression. Standard errors (clustered at the acquirer level) that are robust to both cross-sectional heteroskedasticity and within-firm serial correlation are used in computing $t$-statistics (in brackets). $, * *, * * *$ : statistically significantly different from zero at the $0.10,0.05$, and 0.01 level (two-tailed), respectively. Variable definitions are in the Appendix.

\begin{tabular}{|c|c|c|c|c|}
\hline & $(1)$ & $(2)$ & (3) & (4) \\
\hline Insurance $(1 / 0)$ & $\begin{array}{c}-2.264 * * \\
{[-1.978]}\end{array}$ & $\begin{array}{c}-3.121 * * \\
{[-2.387]}\end{array}$ & & \\
\hline Insurance coverage ratio & & & $\begin{array}{c}-21.045^{* *} \\
{[-2.174]}\end{array}$ & $\begin{array}{c}-27.145^{* * *} \\
{[-2.859]}\end{array}$ \\
\hline All-cash deal (1/0) & $\begin{array}{c}-0.059 \\
{[-0.079]}\end{array}$ & $\begin{array}{c}-0.835 \\
{[-0.935]}\end{array}$ & $\begin{array}{c}0.260 \\
{[0.351]}\end{array}$ & $\begin{array}{c}-0.499 \\
{[-0.560]}\end{array}$ \\
\hline Stock deal $(1 / 0)$ & $\begin{array}{c}-0.160 \\
{[-0.172]}\end{array}$ & $\begin{array}{c}-0.323 \\
{[-0.292]}\end{array}$ & $\begin{array}{c}0.033 \\
{[0.033]}\end{array}$ & $\begin{array}{c}-0.106 \\
{[-0.091]}\end{array}$ \\
\hline Friendly deal (1/0) & $\begin{array}{c}-0.363 \\
{[-0.302]}\end{array}$ & $\begin{array}{c}0.405 \\
{[0.317]}\end{array}$ & $\begin{array}{c}-0.407 \\
{[-0.325]}\end{array}$ & $\begin{array}{c}0.262 \\
{[0.193]}\end{array}$ \\
\hline Relative size & $\begin{array}{c}2.374 \\
{[1.200]}\end{array}$ & $\begin{array}{c}1.794 \\
{[0.846]}\end{array}$ & $\begin{array}{c}3.416^{*} \\
{[1.693]}\end{array}$ & $\begin{array}{c}3.576 \\
{[1.592]}\end{array}$ \\
\hline Unrelated deal $(1 / 0)$ & $\begin{array}{c}0.396 \\
{[0.618]}\end{array}$ & $\begin{array}{c}0.720 \\
{[0.999]}\end{array}$ & $\begin{array}{c}0.435 \\
{[0.679]}\end{array}$ & $\begin{array}{c}0.799 \\
{[1.091]}\end{array}$ \\
\hline Private target $(1 / 0)$ & $\begin{array}{l}1.748^{* *} \\
{[2.041]}\end{array}$ & $\begin{array}{c}1.247 \\
{[1.230]}\end{array}$ & $\begin{array}{l}2.004 * * \\
{[2.212]}\end{array}$ & $\begin{array}{c}1.692 \\
{[1.564]}\end{array}$ \\
\hline Subsidiary target (1/0) & $\begin{array}{l}1.832 * * \\
{[2.253]}\end{array}$ & $\begin{array}{l}1.638^{*} \\
{[1.834]}\end{array}$ & $\begin{array}{l}1.956^{* *} \\
{[2.317]}\end{array}$ & $\begin{array}{c}1.753^{*} \\
{[1.890]}\end{array}$ \\
\hline Log(assets) & $\begin{array}{c}-0.110 \\
{[-0.481]}\end{array}$ & $\begin{array}{c}-0.372 \\
{[-1.378]}\end{array}$ & $\begin{array}{c}-0.375 \\
{[-1.579]}\end{array}$ & $\begin{array}{c}-0.744 * * \\
{[-2.456]}\end{array}$ \\
\hline Market-to-book & $\begin{array}{c}-0.384 \\
{[-0.999]}\end{array}$ & $\begin{array}{c}-0.454 \\
{[-1.060]}\end{array}$ & $\begin{array}{c}-0.532 \\
{[-1.286]}\end{array}$ & $\begin{array}{c}-0.652 \\
{[-1.406]}\end{array}$ \\
\hline Leverage & $\begin{array}{c}-2.932 \\
{[-1.311]}\end{array}$ & $\begin{array}{c}-3.586 \\
{[-1.460]}\end{array}$ & $\begin{array}{c}-1.968 \\
{[-0.885]}\end{array}$ & $\begin{array}{c}-2.846 \\
{[-1.172]}\end{array}$ \\
\hline Stock price run-up (\%) & $\begin{array}{c}-0.002 \\
{[-0.275]}\end{array}$ & $\begin{array}{c}-0.001 \\
{[-0.066]}\end{array}$ & $\begin{array}{c}-0.004 \\
{[-0.465]}\end{array}$ & $\begin{array}{c}-0.004 \\
{[-0.399]}\end{array}$ \\
\hline Free cash flow & $\begin{array}{c}1.675 \\
{[0.588]}\end{array}$ & $\begin{array}{c}4.612 \\
{[1.351]}\end{array}$ & $\begin{array}{c}0.903 \\
{[0.309]}\end{array}$ & $\begin{array}{c}3.950 \\
{[1.143]}\end{array}$ \\
\hline Managerial quality & $\begin{array}{c}0.605 \\
{[1.167]}\end{array}$ & $\begin{array}{l}1.284 * * \\
{[2.293]}\end{array}$ & $\begin{array}{c}0.519 \\
{[1.009]}\end{array}$ & $\begin{array}{l}1.227 * * \\
{[2.205]}\end{array}$ \\
\hline Competitive industry $(1 / 0)$ & & $\begin{array}{c}2.611 \\
{[1.512]}\end{array}$ & & $\begin{array}{l}3.094^{*} \\
{[1.774]}\end{array}$ \\
\hline Unique industry $(1 / 0)$ & & $\begin{array}{c}-1.872 \\
{[-1.311]}\end{array}$ & & $\begin{array}{c}-1.498 \\
{[-0.958]}\end{array}$ \\
\hline Insider ownership (\%) & & $\begin{array}{c}0.010 \\
{[0.356]}\end{array}$ & & $\begin{array}{c}0.032 \\
{[1.205]}\end{array}$ \\
\hline Institutional ownership (\%) & & $\begin{array}{c}0.014 \\
{[0.691]}\end{array}$ & & $\begin{array}{c}0.016 \\
{[0.804]}\end{array}$ \\
\hline Year fixed-effects & Yes & Yes & Yes & Yes \\
\hline Industry fixed-effects & Yes & Yes & Yes & Yes \\
\hline First-stage Shea's partial $R^{2}$ & 0.551 & 0.555 & 0.546 & 0.678 \\
\hline First -stage $F$-test ( $p$-value) & 0.000 & 0.000 & 0.000 & 0.000 \\
\hline Second-stage adjusted $R^{2}$ & 0.091 & 0.132 & 0.105 & 0.155 \\
\hline Number of observations & 554 & 437 & 530 & 416 \\
\hline
\end{tabular}


Table 8

Acquirer abnormal announcement returns and D\&O insurance: Non-serial acquirers

This table includes only acquisitions by non-serial acquirers. A serial acquirer is defined as an acquirer which has more than two deals in the sample. The dependent variable is CAR $(-2,+2)(\%)$. Columns 3 and 4 contain instrumental variables regressions as in Table 7. Standard errors (clustered at the acquirer level) that are robust to both cross-sectional heteroskedasticity and within-firm serial correlation are used in computing $t$-statistics (in brackets). ${ }^{*}, * *, * * *$ : statistically significantly different from zero at the $0.10,0.05$, and 0.01 level (two-tailed), respectively. Variable definitions are in the Appendix.

\begin{tabular}{|c|c|c|c|c|}
\hline & (1) & $(2)$ & (3) & $(4)$ \\
\hline Insurance $(1 / 0)$ & $\begin{array}{l}-3.465^{* *} \\
{[-2.132]}\end{array}$ & & $\begin{array}{l}-3.046^{*} \\
{[-1.761]}\end{array}$ & \\
\hline Insurance coverage ratio & & $\begin{array}{c}-30.44 * * * \\
{[-3.086]}\end{array}$ & & $\begin{array}{c}-32.57 * * * \\
{[-3.321]}\end{array}$ \\
\hline All-cash deal $(1 / 0)$ & $\begin{array}{c}-1.307 \\
{[-0.836]}\end{array}$ & $\begin{array}{c}-1.305 \\
{[-0.872]}\end{array}$ & $\begin{array}{c}-1.046 \\
{[-0.683]}\end{array}$ & $\begin{array}{c}-0.957 \\
{[-0.668]}\end{array}$ \\
\hline Stock deal $(1 / 0)$ & $\begin{array}{c}-0.593 \\
{[-0.305]}\end{array}$ & $\begin{array}{c}-0.489 \\
{[-0.230]}\end{array}$ & $\begin{array}{c}-0.227 \\
{[-0.112]}\end{array}$ & $\begin{array}{c}0.184 \\
{[0.089]}\end{array}$ \\
\hline Friendly deal (1/0) & $\begin{array}{c}1.953 \\
{[0.812]}\end{array}$ & $\begin{array}{c}0.501 \\
{[0.193]}\end{array}$ & $\begin{array}{c}2.109 \\
{[0.809]}\end{array}$ & $\begin{array}{c}0.681 \\
{[0.253]}\end{array}$ \\
\hline Relative size & $\begin{array}{l}3.538^{*} \\
{[1.702]}\end{array}$ & $\begin{array}{c}5.372 * * \\
{[2.361]}\end{array}$ & $\begin{array}{l}3.609^{*} \\
{[1.815]}\end{array}$ & $\begin{array}{c}5.861 * * * \\
{[2.648]}\end{array}$ \\
\hline Unrelated deal $(1 / 0)$ & $\begin{array}{c}-0.443 \\
{[-0.300]}\end{array}$ & $\begin{array}{c}0.04 \\
{[0.029]}\end{array}$ & $\begin{array}{c}-0.493 \\
{[-0.335]}\end{array}$ & $\begin{array}{c}-0.098 \\
{[-0.071]}\end{array}$ \\
\hline Private target $(1 / 0)$ & $\begin{array}{c}1.66 \\
{[0.967]}\end{array}$ & $\begin{array}{c}2.278 \\
{[1.192]}\end{array}$ & $\begin{array}{c}1.765 \\
{[1.029]}\end{array}$ & $\begin{array}{c}2.19 \\
{[1.155]}\end{array}$ \\
\hline Subsidiary target $(1 / 0)$ & $\begin{array}{c}2.198 \\
{[1.525]}\end{array}$ & $\begin{array}{l}2.532 * \\
{[1.714]}\end{array}$ & $\begin{array}{l}2.366^{*} \\
{[1.662]}\end{array}$ & $\begin{array}{l}2.587^{*} \\
{[1.731]}\end{array}$ \\
\hline Leverage & $\begin{array}{c}-1.701 \\
{[-0.416]}\end{array}$ & $\begin{array}{c}3.286 \\
{[0.807]}\end{array}$ & $\begin{array}{c}-1.392 \\
{[-0.333]}\end{array}$ & $\begin{array}{c}4.081 \\
{[1.025]}\end{array}$ \\
\hline Free cash flow & $\begin{array}{c}14.332 * * \\
{[2.200]}\end{array}$ & $\begin{array}{c}12.532 * * \\
{[2.123]}\end{array}$ & $\begin{array}{c}14.211^{* *} \\
{[2.248]}\end{array}$ & $\begin{array}{c}12.523^{* *} \\
{[2.169]}\end{array}$ \\
\hline Log(assets) & $\begin{array}{c}0.45 \\
{[0.969]}\end{array}$ & $\begin{array}{c}-0.4 \\
{[-0.853]}\end{array}$ & $\begin{array}{c}0.393 \\
{[0.856]}\end{array}$ & $\begin{array}{c}-0.425 \\
{[-0.948]}\end{array}$ \\
\hline Market-to-book & $\begin{array}{c}0.749 \\
{[1.649]}\end{array}$ & $\begin{array}{c}0.523 \\
{[1.321]}\end{array}$ & $\begin{array}{l}0.762 * \\
{[1.683]}\end{array}$ & $\begin{array}{c}0.58 \\
{[1.462]}\end{array}$ \\
\hline Stock price run-up (\%) & $\begin{array}{c}-0.012 \\
{[-1.148]}\end{array}$ & $\begin{array}{c}-0.012 \\
{[-1.193]}\end{array}$ & $\begin{array}{c}-0.012 \\
{[-1.127]}\end{array}$ & $\begin{array}{c}-0.014 \\
{[-1.389]}\end{array}$ \\
\hline Managerial quality & $\begin{array}{c}1.298 \\
{[1.068]}\end{array}$ & $\begin{array}{c}1.499 \\
{[1.256]}\end{array}$ & $\begin{array}{c}1.364 \\
{[1.047]}\end{array}$ & $\begin{array}{c}1.499 \\
{[1.243]}\end{array}$ \\
\hline Competitive industry $(1 / 0)$ & $\begin{array}{c}1.303 \\
{[0.724]}\end{array}$ & $\begin{array}{c}2.204 \\
{[1.249]}\end{array}$ & $\begin{array}{c}1.262 \\
{[0.702]}\end{array}$ & $\begin{array}{c}1.974 \\
{[1.168]}\end{array}$ \\
\hline Unique industry $(1 / 0)$ & $\begin{array}{c}-1.627 \\
{[-0.364]}\end{array}$ & $\begin{array}{c}-0.741 \\
{[-0.213]}\end{array}$ & $\begin{array}{c}-1.725 \\
{[-0.390]}\end{array}$ & $\begin{array}{c}-0.669 \\
{[-0.186]}\end{array}$ \\
\hline Insider ownership (\%) & $\begin{array}{c}0.009 \\
{[0.197]}\end{array}$ & $\begin{array}{c}0.062 \\
{[1.470]}\end{array}$ & $\begin{array}{c}0.009 \\
{[0.186]}\end{array}$ & $\begin{array}{c}0.063 \\
{[1.471]}\end{array}$ \\
\hline Institutional ownership (\%) & $\begin{array}{c}-0.018 \\
{[-0.435]}\end{array}$ & $\begin{array}{c}0.017 \\
{[0.451]}\end{array}$ & $\begin{array}{c}-0.015 \\
{[-0.337]}\end{array}$ & $\begin{array}{c}0.02 \\
{[0.528]}\end{array}$ \\
\hline Year and industry fixed-effects & Yes & Yes & Yes & Yes \\
\hline Second-stage adjusted $R^{2}$ & 0.241 & 0.324 & 0.228 & 0.322 \\
\hline Number of observations & 152 & 147 & 152 & 147 \\
\hline
\end{tabular}


Table 9

Acquisition Premiums and D\&O Insurance

This table shows the results from OLS regressions of acquisition premium (Acquisition premium_4 $\mathrm{w}$ $(\%)$ ) on measures of D\&O insurance use. Models 3 and 4 are instrumental variables regressions where the insurance indicator (coverage) is instrumented with fitted values from a first-stage regression on industry mean (median) insurance incidence (coverage) based on three-digit SIC codes and the control variables. Shea's (1997) partial $R^{2}$ is a measure of IV relevance. First-stage F-test is the test of excluded IV in the first-stage regression. Standard errors (clustered at the acquirer level) that are robust to both cross-sectional heteroskedasticity and within-firm serial correlation are used in computing $t$-statistics (in brackets). *, **, $* * *$ : statistically significantly different from zero at the $0.10,0.05$, and 0.01 level (two-tailed), respectively. The coefficients of the constant, year, and industry dummies are omitted for brevity. Variable definitions are in the Appendix.

\begin{tabular}{|c|c|c|c|c|}
\hline & $(1)$ & $(2)$ & (3) & $(4)$ \\
\hline \multirow[t]{2}{*}{ Insurance $(1 / 0)$} & 7.226 & & 7.228 & \\
\hline & {$[0.642]$} & & {$[0.348]$} & \\
\hline \multirow[t]{2}{*}{ Insurance coverage ratio } & & $263.435^{* * *}$ & & $293.409 * * *$ \\
\hline & & [2.890] & & [3.179] \\
\hline \multirow[t]{2}{*}{$\log$ (assets) } & -3.538 & -2.281 & -3.812 & -2.547 \\
\hline & {$[-1.005]$} & {$[-0.648]$} & {$[-0.986]$} & {$[-0.722]$} \\
\hline \multirow[t]{2}{*}{ Market-to-book } & 4.888 & 6.360 & 4.991 & 6.620 \\
\hline & {$[0.876]$} & [1.233] & {$[0.908]$} & {$[1.297]$} \\
\hline \multirow[t]{2}{*}{ Stock price run-up (\%) } & 0.094 & 0.094 & 0.091 & 0.081 \\
\hline & {$[0.841]$} & {$[0.771]$} & {$[0.805]$} & {$[0.680]$} \\
\hline \multirow[t]{2}{*}{ All-cash deal (1/0) } & 18.901 & $20.667^{*}$ & 19.138 & $22.715^{*}$ \\
\hline & {$[1.479]$} & {$[1.738]$} & {$[1.383]$} & {$[1.882]$} \\
\hline \multirow[t]{2}{*}{ Stock deal $(1 / 0)$} & $18.771^{*}$ & 17.526 & $18.443 *$ & 17.109 \\
\hline & {$[1.750]$} & {$[1.447]$} & {$[1.851]$} & {$[1.422]$} \\
\hline \multirow[t]{2}{*}{ Friendly deal (1/0) } & -11.106 & -10.081 & -11.610 & -10.812 \\
\hline & {$[-0.756]$} & {$[-0.765]$} & {$[-0.757]$} & {$[-0.842]$} \\
\hline \multirow[t]{2}{*}{ Managerial quality } & 3.941 & 3.114 & 3.738 & 3.219 \\
\hline & {$[0.913]$} & {$[0.702]$} & {$[0.870]$} & {$[0.722]$} \\
\hline \multirow[t]{2}{*}{ Competitive industry $(1 / 0)$} & 11.042 & 9.073 & 10.667 & 7.334 \\
\hline & {$[0.563]$} & {$[0.508]$} & {$[0.549]$} & {$[0.411]$} \\
\hline \multirow[t]{2}{*}{ Unique industry $(1 / 0)$} & -15.848 & -16.195 & -16.331 & -15.874 \\
\hline & {$[-0.911]$} & {$[-0.925]$} & {$[-0.951]$} & {$[-0.888]$} \\
\hline \multirow[t]{2}{*}{ Insider ownership (\%) } & 0.428 & 0.476 & 0.419 & 0.478 \\
\hline & {$[1.184]$} & {$[1.326]$} & {$[1.155]$} & {$[1.377]$} \\
\hline \multirow[t]{2}{*}{ Institutional ownership (\%) } & 0.390 & 0.389 & 0.402 & 0.381 \\
\hline & {$[1.175]$} & [1.112] & {$[1.224]$} & {$[1.081]$} \\
\hline Year fixed-effects & Yes & Yes & Yes & Yes \\
\hline Industry fixed-effects & Yes & Yes & Yes & Yes \\
\hline First-stage Shea's partial $R^{2}$ & & & 0.513 & 0.117 \\
\hline First-stage $F$-test ( $p$-value) & & & 0.000 & 0.002 \\
\hline Second-stage adjusted $R^{2}$ & 0.203 & 0.236 & 0.201 & 0.237 \\
\hline Number of observations & 116 & 112 & 116 & 112 \\
\hline
\end{tabular}


Table 10

Synergies in mergers with public targets

Panel A reports average (medians in parentheses) combined cumulative abnormal returns (CAR $(-2,+2)(\%))$ of the acquirer and target. Weighting is based on the market values of the acquirer and target firm. $t$-tests are used to determine whether a mean (or difference in means) is significantly different from zero and Wilcoxon $z$ tests are used to determine whether a difference in medians is significantly different from zero. Panels B and C report medians of industry-median-adjusted operating performance after mergers for acquirers with below-median (Low) and above-median (High) ratio of insurance coverage/market value of equity. Year 0 is the year in which the merger is completed. Return on assets (ROA) is net income divided by the market value of total assets at the beginning of the fiscal year, where the market value of total assets is the sum of the market value of equity and the book values of preferred stock and debt (net of cash). Asset turnover (ATO) is sales divided by the market value of total assets at the beginning of the fiscal year. In pre-merger years, industry-median-adjusted operating performance (ROA or ATO) is calculated as the weighted average of the acquirer's and the target's performance minus the weighted average of the industry-median performance using the acquirer's and the target's industry. The weights are based on the market value of total assets of each firm at the beginning of each year. In post-merger years, industry-median-adjusted operating performance is the merged firm's performance (ROA or ATO) minus the weighted average of the acquirer's and the target's industry-median performance, with the weights determined by using the market value of total assets of the acquirer and the target at the beginning of year - 1 . Industry classification is based on three- or fourdigit SIC codes. *, **,***: statistically significantly different from zero at the $0.10,0.05$, and 0.01 level (two-tailed), respectively.

Panel A: Combined acquirer and target cumulative abnormal announcement returns: CAR $(-2,+2)(\%)$

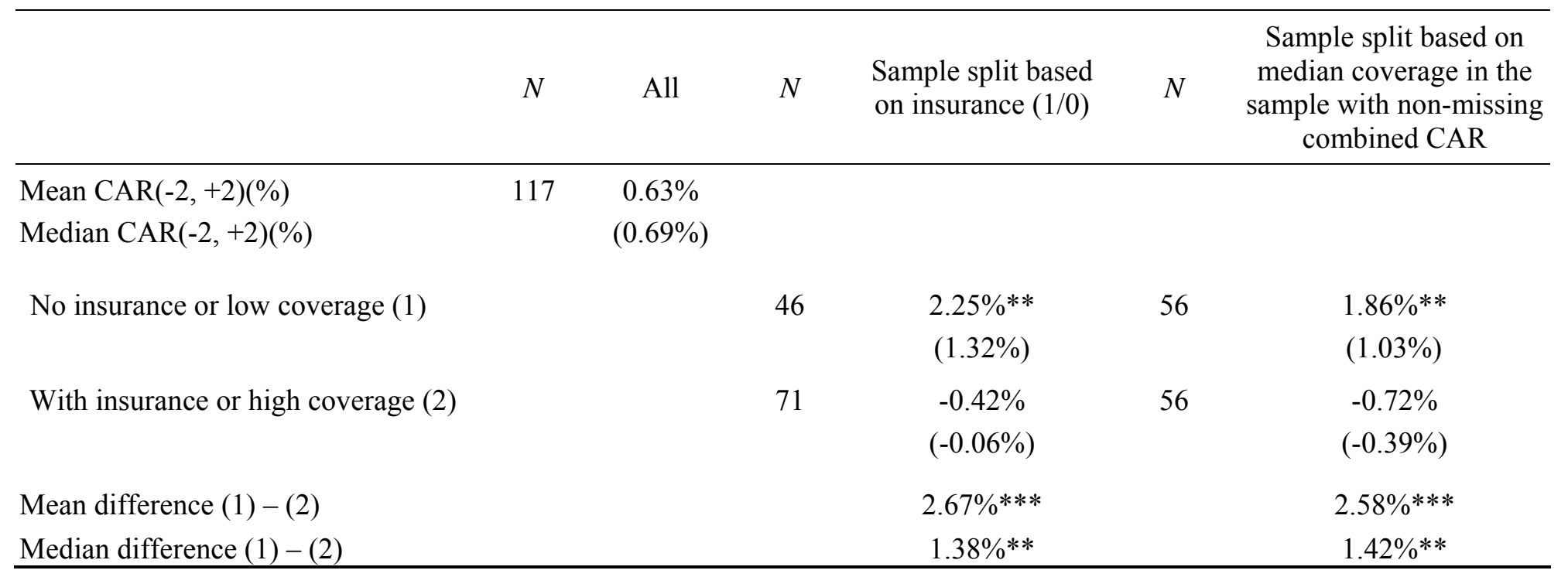


Panel B: Medians of industry-median-adjusted return on assets (ROA)

\begin{tabular}{cccccc}
\hline & & \multicolumn{2}{c}{ Three-digit SIC } & \multicolumn{2}{c}{ Four-digit SIC } \\
\cline { 3 - 6 } Year relative to merger & $N$ & Low coverage & High coverage & Low coverage & High coverage \\
\hline-3 & 56 & 0.036 & 0.026 & 0.032 & 0.013 \\
-2 & 69 & 0.025 & 0.033 & 0.014 & 0.027 \\
-1 & 81 & 0.030 & 0.034 & 0.027 & 0.031 \\
0 & 81 & 0.025 & 0.026 & 0.029 & 0.034 \\
+1 & 81 & 0.035 & 0.015 & 0.032 & 0.024 \\
+2 & 49 & 0.043 & 0.021 & 0.044 & 0.032 \\
+3 & 40 & 0.019 & 0.007 & 0.012 & 0.017 \\
+4 & 28 & 0.028 & 0.017 & 0.022 & 0.022 \\
+5 & 17 & 0.049 & 0.015 & 0.043 & 0.017 \\
Post-3-year-median minus -1 & & -0.002 & $-0.029 * * *$ & -0.001 & $-0.023 * *$ \\
\hline
\end{tabular}

Panel C: Medians of industry-median adjusted abnormal asset turnover (ATO)

\begin{tabular}{cccccc}
\hline & & \multicolumn{2}{c}{ Three-digit SIC } & \multicolumn{2}{c}{ Four-digit SIC } \\
\cline { 3 - 6 } Year relative to merger & $N$ & Low coverage & High coverage & Low coverage & High coverage \\
\hline-3 & 56 & -0.005 & 0.038 & -0.005 & 0.044 \\
-2 & 69 & 0.045 & 0.052 & 0.043 & 0.049 \\
-1 & 81 & 0.058 & 0.050 & 0.031 & 0.045 \\
0 & 81 & 0.071 & 0.074 & 0.019 & 0.057 \\
+1 & 81 & 0.074 & 0.058 & 0.065 & 0.051 \\
+2 & 49 & 0.165 & 0.061 & 0.176 & 0.061 \\
+3 & 40 & 0.175 & 0.026 & 0.183 & 0.019 \\
+4 & 28 & 0.236 & 0.050 & 0.181 & 0.039 \\
+5 & 17 & 0.144 & 0.063 & 0.240 & 0.006 \\
Post-3-year-median minus -1 & & 0.036 & -0.048 & 0.047 & -0.029 \\
\hline
\end{tabular}


Table 11

Changes in abnormal operating performance after mergers with public targets

This table reports the result of Healy, Palepu, and Ruback's (1992) regressions for measuring changes in operating performance around mergers, where the post-merger three-year median of the abnormal operating performance (return on assets or asset turnover) is regressed on the combined acquirer-target industry-adjusted performance in year - 1 . The intercept represents the average change in abnormal operating performance following mergers. Industry classification is based on three-digit SIC codes. Low- and high-coverage are defined in Table 10. Standard errors (clustered at the acquirer level) that are robust to both cross-sectional heteroskedasticity and within-firm serial correlation are used in computing $t$-statistics (in brackets). *, **, ***: statistically significantly different from zero at the $0.10,0.05$, and 0.01 level (two-tailed), respectively. Variable definitions are in the Appendix.

\begin{tabular}{|c|c|c|c|c|}
\hline & \multicolumn{2}{|c|}{ Return on assets } & \multicolumn{2}{|c|}{ Asset turnover } \\
\hline & Low coverage & High coverage & Low coverage & High coverage \\
\hline & $(1)$ & $(2)$ & $(5)$ & $(6)$ \\
\hline \multirow[t]{2}{*}{ Intercept } & -0.021 & $-0.101 * *$ & $0.325^{*}$ & $-0.494 *$ \\
\hline & {$[-0.582]$} & {$[-2.300]$} & [1.934] & {$[-1.952]$} \\
\hline \multirow[t]{2}{*}{ Industry-adjusted ROA in year -1} & $0.420 * * *$ & $0.550 * * *$ & & \\
\hline & {$[3.401]$} & {$[5.003]$} & & \\
\hline \multirow[t]{2}{*}{ Industry-adjusted ATO in year -1 } & & & $0.814 * * *$ & $0.743 * * *$ \\
\hline & & & {$[3.548]$} & [7.579] \\
\hline \multirow[t]{2}{*}{ Log(assets) } & 0.002 & $0.009^{* *}$ & -0.020 & 0.024 \\
\hline & {$[0.572]$} & {$[2.152]$} & {$[-1.582]$} & [1.187] \\
\hline \multirow[t]{2}{*}{ Market-to-book } & 0.008 & $0.011 * *$ & $-0.123 * *$ & 0.045 \\
\hline & {$[0.681]$} & {$[2.325]$} & {$[-2.416]$} & {$[1.674]$} \\
\hline \multirow[t]{2}{*}{ Unrelated deal $(1 / 0)$} & -0.003 & $-0.060 * * *$ & -0.080 & -0.058 \\
\hline & {$[-0.281]$} & {$[-3.568]$} & {$[-1.231]$} & {$[-0.917]$} \\
\hline \multirow[t]{2}{*}{ Friendly deal (1/0) } & 0.018 & 0.037 & 0.127 & 0.247 \\
\hline & {$[0.937]$} & [1.642] & {$[1.677]$} & [1.249] \\
\hline Adjusted $R^{2}$ & 0.304 & 0.567 & 0.596 & 0.646 \\
\hline Number of observations & 40 & 41 & 40 & 41 \\
\hline
\end{tabular}

